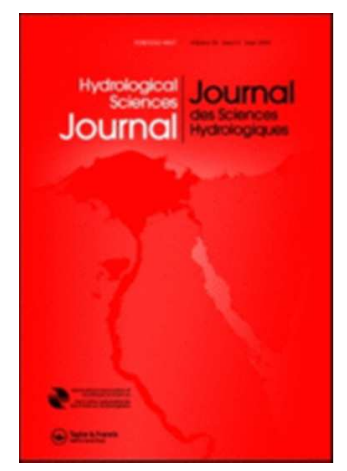

\title{
Forecasting reservoir inflows using remotely sensed precipitation estimates: A pilot study for the River Naryn, Kyrgyzstan
}

\begin{tabular}{|r|l|}
\hline Journal: & Hydrological Sciences Journal \\
\hline Manuscript ID: & HSJ-2014-0082.R1 \\
\hline Manuscript Type: & Original Article \\
\hline Date Submitted by the Author: & n/a \\
\hline Complete List of Authors: & $\begin{array}{l}\text { Dixon, Samuel; Loughborough University, Geography } \\
\text { Wilby, Robert; Loughborough University, }\end{array}$ \\
\hline Keywords: & TRMM, Flow forecast, Toktogul reservoir, Central Asia, Regression model \\
\hline
\end{tabular}

\section{SCHOLARONE ${ }^{\text {m }}$}

Manuscripts 


\section{Forecasting reservoir inflows using}

2 remotely sensed precipitation

3 estimates: A pilot study for the River

4 Naryn, Kyrgyzstan.

5

6 Samuel G. Dixon and Robert L. Wilby

7 Department of Geography, Loughborough University, Loughborough, Leicestershire, LE11 3TU, UK

8

9

10

11

12

27

28 Email: r.l.wilby@lboro.ac.uk

29 Tel: +44 1509223093

HSJ-2014-0082R1

Main body words: 5813

18 October 2014

Corresponding author:

Robert L Wilby

Department of Geography

Loughborough University

Loughborough

Leicestershire

LE11 3TU

Re-submitted to: Hydrological Sciences Journal

30 


\section{Abstract}

32 This study explores the feasibility of applying remotely sensed precipitation

33 estimates (in this case from the Tropical Rainfall Measuring Mission [TRMM]) for

34 forecasting inflows to the strategically important Toktogul reservoir in the Naryn

35 basin, Kyrgyzstan. Correlations between observed precipitation at Naryn and $0.5^{\circ}$

36 TRMM totals is weaker for daily $(r=0.25)$ than monthly $(r=0.93)$ totals, but the Naryn

37 gauge is representative of monthly TRMM precipitation estimates across $\sim 60 \%$ of

38 the basin. We evaluate predictability of monthly inflows given TRMM estimates, air

39 temperature, and antecedent flows. Regression model skill was superior to the Zero

40 Order Forecast (mean flow) for lead times up to three months, and had lower errors

41 in estimated peaks. Over $80 \%$ of the variance in monthly inflows is explained with

42 three month lead, and up to $65 \%$ for summer half-year average. The analysis also

43 reveals zones that are delivering highest predictability and hence candidate areas for

44 surface network expansion.

\section{$46 \quad$ Key words}

47 Remotely sensed precipitation, river flow forecast, Toktogul reservoir, regression 48 model 
50 Early river flow forecasting systems relied on accurate ground based measurements 51 of precipitation at meteorological stations - a basic input requirement that is still 52 difficult to achieve in data sparse and/or physically remote regions (Artan et al., 53 2007). Partial information on precipitation variation in space and time continues to 54 limit the development of flow forecasts for infrastructure operation and hazard 55 warning (Bitew et al., 2012; Kekete et al., 2004). Even where data exist, absence of 56 treaties for information sharing can hinder modelling and management of extreme 57 events in transboundary situations (Hossain, 2007).

58 Remotely sensed, near real-time precipitation estimates have the potential to 59 60 address these shortcomings (Hughes, 2006; Su et al., 2008; Collischonn and Pante,

60
2011) and may offer particular advantages for strengthening flow forecasts for large, transboundary river basins (Balthrop and Hossain, 2010). These capabilities have attracted growing attention from researchers and national agencies alike, with shortterm flood forecasting models utilising passive microwave data for both precipitation and discharge estimation (e.g., Hopson and Webster, 2010; Hirpa et al., 2013). The purpose of this paper is twofold. First, we assess the accuracy of a remotely sensed precipitation product for a strategically significant river basin in Central Asia. Second, we investigate the potential for river flow forecasting based on remotely sensed precipitation, surface temperature and gauged discharge, over monthly to seasonal horizons. We evaluate the data and forecasting techniques using flows in the Syr Darya, Kyrgyzstan upstream of the Toktogul reservoir. This system was chosen because of the importance of the basin as a 'water tower' for sustaining livelihoods downstream (Immerzeel et al., 2010). In addition to socio-economic challenges the region also faces a range of geophysical and meteorological hazards.

74 Earthquakes and landslides are common in the Tien Shan, with most of the 75 population of Kyrgyzstan living in areas of high or very high seismic hazard (UNDP, 76 2012). The primary meteorological hazard in the Syr Darya is flooding, which can be 77 exacerbated by reservoir operations (UNDP, 2012).

78 The following section provides more background to the pilot study region and data. 79 Section 3 describes the methods used to evaluate satellite products, and to build 
statistical forecast models of reservoir inflows, drawing on input data from different scales and locations within the basin. Section 4 presents the results of these analyses, and Section 5 offers interpretations of model skill based on the hydrometeorological processes within the basin. Finally, section 6 briefly considers the transferability of the approach beyond the Naryn-Syr Darya cascade and offers suggestions for further research.

86

\section{Study area and data}

88 The Naryn basin is located in the Central Tien Shan mountain range of Kyrgyzstan, 89 the headwaters of the Syr Darya River (Figure 1). The Syr Darya is one of two major 90 rivers (along with the Amu Darya) that supplies water to the Central Asian Republics.

91 The basin area of the Naryn is $55,944 \mathrm{~km}^{2}$ with an elevation range of more than

924,000 m including major mountain belts such as the Kyrgyz Range in the north, 93 Talas Ala Toosu and Fergana ranges in the southwest (Kriegel et al., 2013). The 94 Naryn is fed by a major tributary below Song Kol Lake which runs during the melt 95 season (April to September). Land cover is mainly grass and shrub, with pastoral 96 farming on mountain sides, and some arable crop and hay production in valleys 97 sustained by irrigation.

98 The Tien Shan mountain range has a continental climate with the main source of 99 moisture originating from the Atlantic Ocean (Aizen et al., 1995a). Several weather 100 systems meet over the region, including westerly air streams, the Siberian 101 anticyclone and south/south-westerly cyclonic circulations (Aizen et al., 1995a; 2001).

102 The mountains prevent penetration of moisture into central areas resulting in low 103 winter precipitation, with maximum totals typically occurring in June and July (Aizen 104 et al., 1995a; 1996). Orographic factors produce a general decrease in precipitation 105 and temperature along a north-west to south-east gradient (Sorg et al., 2012, 106 Karaseva et al., 2012). Temperatures vary from $30^{\circ} \mathrm{C}$ in the western valleys in 107 summer to $-25^{\circ} \mathrm{C}$ in the glacierised regions in winter, but values as low as $-50{ }^{\circ} \mathrm{C}$ 108 have been recorded in the Ak-Say valley. Snow depth is dependent upon aspect 109 relative to the western air masses, and an average melt season of $\sim 70$ days has 110 been observed in northern parts of the region (Aizen et al., 1995a; b). 
111 The Naryn River has mean annual discharge of $13.8 \mathrm{~km}^{3}$ with more than $50 \%$ of the 112 flow originating from snow and glacier melt (Savoskul et al., 2003). The Syr Darya 113 has been extensively managed to re-allocate water to satisfy the needs of countries 114 through which it flows (Kyrgyzstan, Uzbekistan, Tajikistan and Kazakhstan). Six 115 large and several smaller reservoirs were built along the Syr Darya by the Soviet 116 Union, providing a total storage capacity of $\sim 35 \mathrm{~km}^{3}$ (Savoskul et al., 2003). These 117 reservoirs have contributed to a management system described as one of the most 118 complicated in the world (Raskin et al., 1992).

119 Water diversions from the Syr Darya have contributed to the Aral Sea losing two120 thirds volume since 1957 (UNEP, 2008). Contention also surrounds the differing 121 interests of Kyrgyzstan to release water for hydropower generation during the winter, 122 versus downstream needs of Uzbekistan and Kazakhstan for irrigation in summer 123 (Karaev, 2005). During the Soviet era such energy-water trade-offs were managed 124 centrally (Hodgson, 2010); post-independence Kyrgyzstan has increased the volume 125 of water released from Toktogul during winter months for hydropower to reduce the 126 risk of black outs (Umaraliev, 2012). Attempts have been made to resolve these 127 competing interests (Kraak, 2012a) with operation of Toktogul reservoir central to 128 such discussions due to the immense storage capacity $\left(19.5 \mathrm{~km}^{3}\right)$ and position of the 129 impoundment within the system (Figure 1).

130

\section{$131 \quad 2.1$ Remotely sensed precipitation}

132 UNDP (2012) concluded that as well as greater regional cooperation, there is also a 133 need to strengthen monitoring and modelling capacity in the region. Remotely 134 sensed precipitation data offer a means of filling these gaps. Several satellite 135 precipitation products are available including: the Tropical Rainfall Measuring 136 Mission (TRMM) and its successor the Global Precipitation Measurement (GPM) 137 Core Observatory (launched February 2014) ${ }^{1}$; Precipitation Estimation from 138 Remotely Sensed Information using Artificial Neural Networks (PERSIANN); and 139 NOAA Center for Satellite Applications and Research (STAR).

\footnotetext{
${ }^{1}$ http://www.nasa.gov/content/goddard/nasa-rainfall-satellite-out-of-fuel-but-continues-to-providedata/\#.VDLDG nueuJ
} 
140 This study demonstrates proof of concept using the TRMM Multi-satellite

141 Precipitation Analysis (TMPA) but our approach is applicable to other sources of

142 remotely sensed data. The TRMM product was constructed in four stages (NASA,

143 2011). First, microwave precipitation estimates are calibrated and combined; second,

144 infrared precipitation estimates are created with the aid of the calibrated microwave

145 precipitation estimates; third, microwave and infrared estimates are combined; and

146 fourth, rain gauge data are incorporated into the final estimate. Microwave

147 precipitation estimates are collected by multiple satellites (TRMM, DMSP, Aqua and

148 NOAA) which cover the area between $50^{\circ} \mathrm{N}$ and $50^{\circ} \mathrm{S}$. Infrared data are collected by

149 the TRMM satellite and provides high temporal and spatial coverage. Rain gauge

150 data used in TRMM were obtained from Global Precipitation Climatology Centre

151 (GPCC) and the Climate Assessment and Monitoring System (CAMS) (Huffman et

152 al., 2007; Huffman and Bolvin, 2013).

153 Two previous studies have evaluated TRMM products for the Tien Shan Mountains.

154 One compared TRMM with every rain gauge in Kyrgyzstan (Karaseva et al., 2012);

155 the other examined basins in the mid Tien Shan Mountain range (Ji and Chen, 2012).

156 Both found that TRMM underestimated precipitation in mountainous areas and

157 during heavy precipitation events, possibly due to difficulties in detecting shallow,

158 orographic rainfall (Adler et al., 2003). Aspect was found to be an important factor

159 with south facing slopes having higher accuracy and correlation compared with north

160 facing slopes. However, there is low confidence in this finding because of limited

161 data for south facing slopes (Ji and Chen, 2012). Karaseva et al. (2012) report low

162 correlations in the vicinity of large lakes (e.g., Issyk Kul and Toktogul) due to

163 contamination of the microwave signal by water bodies and mountains within the

164 sensor footprint. Strongest correlations were found in the high plateaus, including for

165 the Naryn gauge (Karaseva et al., 2012).

166 Rain gauge data are incorporated differently depending on aggregation period. The

167 3B43 (V7) (monthly precipitation estimate) is produced by first summing original

168 three-hour values by calendar month. Second, monthly precipitation gauge analysis

169 is used to create a large scale bias adjustment to the satellite estimates. Lastly,

170 monthly gauge adjusted satellite estimates are combined directly with gauge

171 precipitation via inverse error variance weighting to create the final product. The

172 3B42 (V7) dataset (daily precipitation estimate) is derived by scaling the original 
173 three-hourly estimates so they sum approximately to the monthly gauge adjusted

174 satellite-gauge combination value calculated in step two of the 3B43 (V7) procedure

175 (Huffman and Bolvin, 2013). Henceforth, we refer to 3B42 (V7) as daily TRMM, and $1763 \mathrm{~B} 43$ (V7) as monthly TRMM.

177 Monthly and daily TRMM were obtained at $0.5^{\circ}$ resolution from the TRMM Online 178 Visualisation and Analysis System (TOVAS) for every cell in the Naryn basin for the 179 years 1998 to 2010 inclusive. In addition, monthly and daily data were downloaded 180 for the same time period but at $0.25^{\circ}$ resolution for cells within the $0.5^{\circ}$ grid nearest 181 to the Naryn meteorological station (Figure 1).

182

\subsection{Ground-based measurements}

184 Daily meteorological and hydrological data were collected as part of a European 185 Bank for Reconstruction and Development (EBRD) project investigating downstream 186 consequences of climate change and flow regulation on the River Naryn (Wilby et al., 187 2011). Daily precipitation totals and mean daily temperature were obtained for the 188 meteorological station at Naryn for the years 1981 to 2010 (Figure 1). This single station was chosen for two reasons. First, an earlier analysis of all stations in Kyrgyzstan showed that the correlation between TRMM and gauge precipitation was strongest at Naryn (Karaseva et al., 2012). Second, the site is centrally located within the Naryn basin, and the record is unbroken for the period over-lapping with 193 river flow data. Daily discharges were obtained for a site upstream of Toktogul for the years 2000 to 2009 . The inflow record has several months with missing data which were filled by interpolating from monthly mean values.

\section{Methods}

198 The analysis proceeded in two stages. First, we evaluated the quality of daily and 199 monthly remotely sensed (TRMM) precipitation estimates in the vicinity of the Naryn 200 meteorological station. Second, we assessed the feasibility of forecasting monthly 201 inflows to Toktogul based on a blend of remotely sensed and ground-based 202 observations. Each step is described below. 


\section{$203 \quad 3.1$ Evaluation of TRMM products}

204 We extend earlier analyses by comparing Naryn and TRMM precipitation at different 205 spatial and temporal resolutions. We recognise that it is not possible to undertake a 206 fully independent test of TRMM in data sparse regions because it is likely that data 207 from available meteorological stations have been assimilated by the algorithm. 208 Inspection of the gauges used for Kyrgyzstan confirms that this is the case ${ }^{2}$. 209 Consistent with other networks in the post-Soviet era, the number of gauges 210 assimilated by TRMM declined from 23 (1998) to 12 (2010), but data for the station 211 at Naryn was blended with other sites throughout our study period (Figure 2).

212 With these points in mind we investigated specific instances in which there are major 213 discrepancies between TRMM and Naryn gauge data. Monthly mean and annual 214 precipitation totals were calculated for the $0.5^{\circ}$ TRMM cell overlying the Naryn 215 meteorological station for the years 1998 to 2010. Likewise, cumulative precipitation 216 totals and distributions were derived for the nearest $0.25^{\circ}$ and $0.5^{\circ}$ TRMM cells for 217 the same period. The false alarm ratio was calculated for each month as the fraction 218 of days on which TRMM detects precipitation but the gauge did not, divided by the 219 total number of days on which TRMM measured precipitation (Scheel et al., 2011).

220 Next, the non-parametric Spearman rank correlation coefficient was estimated using 221 daily time series for the same cells. This was followed by a wider analysis of 222 covariance across all cells in the Naryn basin in which data were stratified by 223 calendar month and season. Finally, all cells, permutations of concurrent and lagged 224 (0 to 3 months) TRMM precipitation, and moving averages (0 to 6 months) were 225 correlated with monthly river flow at Toktogul. This was undertaken in order to 226 identify the TRMM cell(s) and area(s) of the basin, lag interval ( $t$ ), and averaging 227 period $(m)$ that potentially yield predictability of inflows.

\subsection{River flow estimation}

230 Following earlier studies we evaluated various combinations of predictor variable, 231 averaging period and lag interval to develop multiple-linear regression models of

\footnotetext{
${ }^{2}$ The GPCC visualizer enables inspection of sites used in TRMM: http://kunden.dwd.de/GPCC/Visualizer
} 
232 monthly inflow to Toktogul for the period May 1999 to July 2010 (Schär et al., 2004; 233 Archer and Fowler, 2008; Magar and Jothiprakash, 2011; and Pal et al., 2013).

234 Available monthly variables were precipitation and temperature observations at 235 Naryn, basin average TRMM precipitation, lagged and time-averaged TRMM 236 precipitation from individual cells, and dummy variable for month to capture the 237 annual cycle (Table 1). The dummy variable regression weights give the flow 238 anomaly with respect to a reference month (in this case December) once the 239 influence of other predictors has been accounted for.

240 Regression modelling proceeded in two steps. First, the large number of lagged, 241 time-averaged and spatially-explicit candidate variables was reduced to a smaller set 242 of statistically significant, independent predictors. Second, the forecast skill of 243 chosen predictors was determined using cross-validation. These stages ensure that 244 the most parsimonious models, with out of sample forecast skill, are constructed.

245 We began by examining simple linear regression relationships between runoff in the 246 summer snow melt season (April to September) as a function of individual predictors: 247 year, precipitation, temperature and runoff in the preceding winter (October to 248 March). This split-year approach has been applied to other runoff records in Central 249 Asia and informs the preliminary selection of candidate predictor variables for sub250 seasonal forecast models (e.g., Schär et al., 2004; Pal et al., 2013). Preferred 251 monthly variables were then screened by stepwise multiple-linear regression, 252 terminating at the point where inclusion of additional variables did not improve the 253 amount of explained variance (when adjusted for sample size and number of 254 predictors). Optimal sets of predictors of monthly discharge (Q) were identified for 255 concurrent $(t)$, one $(t+1)$, two $(t+2)$ and three $(t+3)$ months lead time.

256 Regression model skill was then assessed using cross-validation by which monthly $257 Q$ for individual years was predicted using models built on other years of data. For 258 instance, flows for the year April 1999 to March 2000 would be predicted by a model 259 calibrated on data for April 2000 to March 2010. Year-by-year a full series of 260 predicted flows was built enabling validation against data not used in model 261 calibration. Available records for Toktogul and TRMM permit cross-validation of 11 262 year-long segments of data, each with their own regression parameter sets. This 263 provides a more stringent test of model skill than measures of calibration fit to the 
264 whole data. Note that, however, an operational version of the model would be fit to 265 the selected predictor set using the entire record then recalibrated periodically as 266 more data become available.

267 All model predictions were benchmarked with respect to the Zero Order Forecast 268 (ZOF): the amount of explained variance that can be obtained from the simplest 269 possible model - in this case the long-term monthly mean flow. For comparability, 270 identical segments of data were used for estimating the long-term mean as those 271 entered into the 11 cross-validated regression models. The HydroTest tool (Dawson 272 et al., 2007) was used to derive five metrics of model forecast skill: Root Mean 273 Squared Error (RMSE); A Information Criteria (AIC); Nash-Sutcliffe Coefficient (NSC); 274 Percentage Error in Peak (PEP); and the Mean Absolute Relative Error (MARE).

275

2764 Results

277 With the caveat about lack of full independency of data in mind, we first assessed 278 realism of TRMM precipitation estimates at different temporal scales using the gauge 279 data at Naryn. These data were then used to build and validate models of monthly 280 inflows to Toktogul with forecast horizons of up to three months.

281

282

\subsection{Evaluation of TRMM products}

283 When compared with gauge precipitation at Naryn, $0.5^{\circ}$ TRMM estimates totals 284 during the accumulation (October to March) and melt-season (April to September) 285 with $-1 \%$ and $+11 \%$ bias respectively. The equivalent biases for the nearest $0.25^{\circ}$ 286 TRMM cell are $-2 \%$ and $+5 \%$. The largest over-estimation by TRMM occurs in July, 287 August and September (Figure 3a). Conversely, $0.5^{\circ} \mathrm{TRMM}$ April totals 288 underestimate gauge totals by $16 \%$. The monthly false alarm ratio for daily 289 precipitation occurrence varied between 0.41 (March) and 0.67 (September).

290 Figure 3b shows the variability in annual gauge precipitation with 2003 having more 291 than twice the total of 2006. TRMM overestimates the annual total in the majority of 292 years, however, monthly time-series show strong correlation with the gauge at both $2930.25^{\circ} \mathrm{TRMM}(\mathrm{r}=0.86)$ and $0.5^{\circ} \mathrm{TRMM}(\mathrm{r}=0.86)$ resolutions (Figure 4). Overall, the 
294 correlation between monthly gauge and TRMM is strongest in February, September 295 and November ( $r=0.94)$ and weakest in May $(r=0.16)$ and July $(r=0.66)$. This is 296 explained by three significant discrepancies which occurred in May 2003, July 2006 297 and July 2010 when $0.5^{\circ}$ TRMM overestimates gauge totals by $72.1 \%, 99.7 \%$ and 298 $199.6 \%$ respectively. Over the course of the 13 year period, $0.25^{\circ} \mathrm{TRMM}$ and $0.5^{\circ}$

299 TRMM over-estimate the cumulative total at Naryn by $5 \%$ and $10 \%$ respectively with 300 the departure beginning at the May 2003 anomaly (Figures 5).

301 Consistent with earlier studies (Karaseva et al., 2012; Ji and Chen, 2012), TRMM 302 over-estimates the frequency of light precipitation days, and under-estimates the 303 occurrence of heavy precipitation (Figure 6). However, it is evident that $0.25^{\circ} \mathrm{TRMM}$ 304 provides a better match to the cumulative percentile distribution than $0.5^{\circ} \mathrm{TRMM}$. 305 The correlation between daily gauge and TRMM totals is weak $(r=0.25)$ compared 306 with monthly totals ( $r=0.93$ ) (Figure 7). This is to be expected because the bias 307 correction procedure within TRMM scales sub-daily amounts such that their monthly 308 aggregate converges with that of the monthly gauge total (Huffman et al., 2007).

309 The strength of correlation between gauge precipitation and $0.5^{\circ}$ TRMM totals varies 310 with distance from the meteorological station. Marginally stronger correlations are 311 found in upwind TRMM cells for daily series (Figure 8a), and to the north and west 312 of Naryn for monthly series (Figure 8b). These correlation surfaces show the extent 313 to which the record at Naryn might be representative of precipitation elsewhere in the 314 basin (assuming that TRMM values are 'truth').

\subsection{River flow estimation}

317 Discharge in the summer half-year (April to September) is significantly related to 318 winter TRMM precipitation totals averaged across the Naryn basin (PA) or over the 319 most sensitive sub-basin (PO) (Table 2). Precipitation measured at Naryn and 320 antecedent discharge are weakly related to summer flow (but are statistically 321 insignificant predictors since $p>0.05$ ). Winter temperatures at Naryn and time (year) 322 have no predictive skill over the fit period. This is consistent with the findings of 323 Schär et al. (2004) and Schiemann et al. (2007) for the Syr Darya as a whole. 
324 Monthly discharge typically rises from a minimum in February to maximum in June. 325 However, peak flows are subdued during low precipitation years such as 2007 and 326 2008, arrive earlier in warm years (2006), or later in cold years (2009) (Figure 9). 327 This inter-annual variability would not be captured by a ZOF based on the long-term 328 monthly mean flow alone. Nonetheless, the ZOF still explained $81 \%$ of the variance 329 in monthly discharge entering Toktogul and sets a challenging minimum standard for 330 evaluating more elaborate models.

331 Figure 10 shows the amount of variance in monthly discharge explained by TRMM 332 for different lag intervals (zero to three months). The cells with greatest explained 333 variance at zero lag include eastern mountain areas with seasonal snow cover and 334 glacier storage, as well as Song-Kul Lake (cell $41.5^{\circ} \mathrm{N}, 74.75^{\circ} \mathrm{E}$ ) during the melt 335 season. As the length of lag interval increases the zone producing greatest 336 predictability migrates westwards. Even at forecast horizon $\mathrm{t}+3$ the amount of 337 variance in flows explained by TRMM still exceeds $30 \%$.

338 The correlation between river flow and candidate predictors was assessed by 339 systematically varying lead-time ( $t+0$ to $t+3$ months) and averaging period (1 to 6 340 months) for monthly temperature and precipitation at Naryn, the TRMM basin 341 average precipitation, and the optimum TRMM cell(s) (identified from Figure 10). 342 The correlation coefficient for temperature is strongest with no lead-time $(t+0)$ or 343 smoothing ( $r=0.73$ ) (Figure 11). Greater lead-times and longer averaging periods 344 show weak but statistically significant correlations ( $r>0.17)$ that eventually become 345 negative as the temperature and flow regimes are in anti-phase.

346 The correlation with Naryn precipitation is strongest for $t+0$ when averaged over the 347 previous three months $(r=0.74)$ (Figure 11). Lead-time $t+1$ correlations are 348 strengthened by averaging over two months $(r=0.68)$. The correlation is statistically 349 significant up to $t+3$ months if there is no averaging $(r=0.28)$. Lead-time correlations 350 are strengthened (relative to Naryn) when applying basin area or optimum TRMM 351 cells. For comparison, these predictors yield significant $\mathrm{t}+3$ (no-averaging) 352 correlations $r=0.39$ and $r=0.43$ respectively. Regardless of the averaging period, no 353 significant correlations were found for any TRMM product (whether single cell or 354 basin average) beyond $t+3$, indicating a limit to predictability from this data source. 
355 Estimation of current flows (Q0) was improved by including antecedent discharge 356 and TRMM precipitation from the most highly correlated cell (smoothed over four 357 months) alongside the monthly dummy variable (Tables 3 and 4). The best predictor 358 set for the one month ahead flow forecast model (Q1) also includes temperature 359 (lag-1) (Tables 3 and 4). Regression fit remains superior to the ZOF fit for two (Q2) 360 and three (Q3) month lead-times but these do not incorporate antecedent 361 temperatures. In fact, temperature explains only $9 \%$ and $1 \%$ of the variation in flow 362 at $\mathrm{t}+2$ and $\mathrm{t}+3$ months respectively. Only the optimum TRMM cell provides 363 predictability in Q3 beyond that which can be achieved by the monthly mean flow 364 alone (Tables 3 and $\mathbf{4}$ ).

365 Given the limited data, cross-validation was used to compare predictive skill of 366 regression models relative to the ZOF over forecast horizons $t+1$ to $t+3$ months 367 (Figure 12). According to the chosen performance metrics, Q1, Q2 and Q3 models 368 are superior to ZOF for all diagnostics, except the MARE for Q3 (Table 5). Hence, 369 regression models have lower RMSE and AIC and higher NSC than the ZOF up to 370 Q3. Regression models also have lower errors in the estimated peak, even though 371 these are still under-predicting by typically 20 to $30 \%$ (compared with $35 \%$ for ZOF).

372 The circumstances under which there are large $(t+1)$ forecast errors were explored 373 through closer inspection of daily series of precipitation at Naryn and daily inflow at 374 Toktogul (Figure 13). For example, the forecasted peak monthly flow in 2002 is too 375 low and too late (see Q1 model in Figure 12) because heavy precipitation in late 376 June 2002 is smoothed and lagged by the model such that it impacts estimated flows 377 in July 2002. In this case, the monthly time-step of the model is simply too coarse to 378 resolve the observed near synchronous daily rainfall-runoff response in June. Other 379 discrepancies may be attributed to interpolation of missing daily flows from monthly 380 means (such as the overestimation of discharge during June to September 2007).

381

382

\section{Discussion}

383 Here we interpret our results in the context of other river flow forecast models 384 developed for the region, and from physical reasoning about the underlying hydro385 climatic processes. 


\subsection{Evaluation of TRMM products}

388

The quality of TRMM products has been reviewed elsewhere from the perspective of

389 skill linked to temporal and spatial resolution (Scheel et al., 2011) or physical

390 environment (Berg et al., 2006); performance and corrections needed in

391 mountainous terrain (Condom et al., 2011; Matzler and Standley, 2000; Ji and Chen, 392 2012); local micro-meteorological and orographic effects (Petty, 2001; Barros et al., 393 2004); snowfall detection and evaluation (Gebremichael et al., 2010; Ji and Yu, 2013); and utility for hydrologic prediction (Yong et al., 2012).

395

These studies show that assessing the quality of remotely sensed precipitation

396 estimates is not straightforward. First, lack of ground measurements limits scope to 'ground truth' satellite data (Ebert et al., 2007). Some studies resort to spatial 398 interpolation to infill between stations, but this introduces additional uncertainties ( $\mathrm{Ji}$ and Chen, 2012). Second, interpretations are complicated when comparing point measurements from gauges with area-averages from satellites because spatial averaging can lead to over-estimation of precipitation occurrence or reduce the magnitude of extreme events relative to local observations (Scheel et al., 2011).

403 Third, gauge data are accumulated over fixed intervals (such as 3-hourly or daily totals) whereas TRMM is a snapshot measurement (Scheel et al., 2011).

Good agreement between the Naryn gauge and TRMM precipitation during the accumulation period implies that the latter is able to estimate snowfall totals well at this site (Figure 3). This is contrary to some studies that assert TRMM should not be used without calibration for snowfall (Gebremichael et al., 2010; Yong et al., 2012). It is possible that the rate applied to snowfall $\left(0.1 \mathrm{~mm}\right.$ hour $\left.{ }^{-1}\right)$ is close to that observed 410 at Naryn which, along with relatively low totals during winter months, results in a 411 small absolute bias. However, it must be kept in mind that the accuracy of the gauge 412 for snowfall is also unknown. Therefore, it is unclear whether the gauge or TRMM 413 estimate for May 2003 is most trustworthy. TRMM gave $40 \mathrm{~mm}$ of precipitation on 414 one day whilst the gauge recorded zero, followed by two days of rainfall measured 415 by the gauge totalling $30 \mathrm{~mm}$ that TRMM estimated to be less than $5 \mathrm{~mm}$. It is 416 conceivable that during this time very few if any of the TMPA instruments covered 417 the study area, thereby reducing the accuracy of the TRMM estimate (Huffman et al., 
418 2007). Alternatively, observed precipitation may have been aggregated over more 419 than one day or entered incorrectly against these dates.

420

421

422

423

424

425

426

427

428

429

430

431

432

433

434

435

436

437

438

439

440

441

442

443

444

445

446

447

448

TRMM overestimated the frequency of occurrence (not shown) and total precipitation in July, August and September (Figure 3). The relatively high false alarm ratio at this time could be linked to localised heavy precipitation events under southerly monsoon airflows. Such events may be detected by the area estimates of TRMM but were missed by point measurements at the gauge (Bothe et al., 2012; Bell and Kundu, 2003; Bowman, 2004). This is supported by the fact that the highest overestimation occurred in the lower half of the $0.5^{\circ}$ TRMM cell - the area furthest from the gauge.

The correlation surfaces (Figure 8) partly reflect the time-varying influence of neighbouring gauges within the domain. Overall, the $r \geq 0.7$ correlation field (i.e., more than $50 \%$ variance explained) for monthly amounts covers 21 out of 35 cells in the study area (Figure $\mathbf{8 b}$ ). In other words, the Naryn record is strongly correlated with TRMM precipitation estimates over approximately $60 \%$ of the basin area. The Naryn record is least representative of TRMM values in the Fergana Range (the southwest portion of the basin, Figure 1). Karaseva et al. (2012) and the GPCC visualizer show a cluster of five gauges in this area (Figure 2) which presumably exert a stronger influence than Naryn on local TRMM estimates.

\subsection{River flow estimation}

A growing number of studies are exploring the application of remotely sensed information in hydrological modelling (e.g., Yilmaz et al., 2005; Artan et al., 2007; Su et al., 2008; Bookhagen and Burbank, 2010; Stisen and Sandholt, 2010; Wilby and $\mathrm{Yu}, 2013)$. Previous research shows that model skill can be improved by bias correcting TRMM precipitation estimates, or by blending TRMM with gauge data to simulate runoff (Yu et al., 2011; Bitew et al., 2012). Many studies have focused on large scale modelling (medium/ large basins to global scale); relatively few examine the utility of satellite data for runoff simulation at smaller scales (Hong et al., 2007a; Milewski et al., 2009). It is also recognised that different satellite products can yield different river flow simulations even when passed through the same hydrological model (Chintalapudi et al., 2012). Arid and semi-arid basins can be particularly 
449 challenging to model with satellite precipitation estimates because of localised, 450 heavy precipitation events, coupled with strongly non-linear rainfall-runoff processes 451 (Sagintayev et al., 2012).

452 Earlier research into river flows within the Naryn/Syr Darya basins examined how 453 climate change could impact water resources with and without adaptation (e.g., 454 Siegfried et al., 2012; Ismaiylov et al., 2007; Wilby et al., 2011). Others have used 455 satellite precipitation estimates to calibrate models. For example, Immerzeel et al. 456 (2012) applied a conceptual model with PERSIANN satellite precipitation inputs to 457 assess climate change impacts on water resources. Pereira-Cardenal et al. (2011) 458 used TRMM precipitation with radar altimetry to produce near real-time simulations 459 of Toktogul reservoir water levels.

460 Savoskul et al. (2003) observed that a substantial fraction of winter precipitation 461 contributes to runoff with delay due to seasonal and perennial storage of 462 precipitation in snow and ice. Onset of snowmelt occurs later in the year at higher 463 elevations so these regions might be expected to contribute at longer lag intervals. 464 This is indeed the case, with strongest correlations for delayed runoff from the 465 mountain ranges in the north and southwest of the basin. A further factor is the 466 spatial variation in magnitude of the spring peak in precipitation. Aizen et al. (1996; 467 1997) report that areas below 2,500 $\mathrm{m}$ have two maxima with the main occurring 468 between March-May; whereas areas above 2,500 $\mathrm{m}$ have a single maximum 469 between May-July. They also noted that the proportion of annual precipitation 470 occurring during spring varies from 35-45 \% in areas below 2,500 m compared to 45$47155 \%$ above $2,500 \mathrm{~m}$.

472 Schär et al. (2004) assumed that accumulated runoff for the Syr Darya in summer 473 (May to September) is a linear function of accumulated precipitation in the preceding 474 winter and spring (December to February, March and April). Temperature potentially 475 influences contributions from glacier melt, timing of melt season onset and proportion 476 of total precipitation in liquid state. However, their stepwise regression model of 477 summer runoff omitted all temperature variables, depending instead on precipitation 478 during winter (December to February), March and April alone despite a high degree 479 of glaciation of the test basin. 
480 Predictability of summer flows into Toktogul appears to be maximised by using 481 TRMM precipitation estimates for the cell over Song-Kul Lake (Figure 1). The TRMM 482 basin average for winter also surpassed observed precipitation at Naryn as a 483 predictor. This suggests that seasonal inflows to Toktogul may be routinely 484 forecasted using publicly available satellite products and regression models akin to 485 those shown in Table 2. As more satellite and river flow data become available it will 486 be possible to re-evaluate the stationarity of model parameters, and to discern 487 possible long-term augmentation of summer flow by glacier wastage (Kriegel et al., 488 2013).

489 In the meantime, temperature was found to be a statistically insignificant predictor of 490 summer discharge and was retained in only one of the four monthly models 491 developed for the Naryn (Tables 3 and 4). Once the seasonal snow and ice melt 492 regime is captured by the monthly dummy variable, the remaining temperature effect 493 is negative: months preceded by higher air temperatures typically have lower than 494 average runoff. This could be interpreted as earlier onset of melting, greater 495 evaporative losses at lower elevations, or as reflecting the weak negative correlation $496(r=-0.27)$ between summer temperature and precipitation. A negative (but statistically 497 non-significant) regression parameter between air temperature and summer runoff 498 has also been reported for the Syr Darya to Chinaz (Schiemann et al., 2007). More 499 generally, positive temperature anomalies and suppressed summer convective 500 precipitation over Central Asia are associated with strong Indian summer monsoons 501 (Schiemann et al., 2007).

502

\section{Conclusions}

504 The purpose of this paper was to explore the feasibility of forecasting monthly and 505 seasonal reservoir inflows given minimal surface data and remotely sensed (TRMM) 506 precipitation estimates. Toktogul reservoir was chosen to test the approach because 507 of the economic significance of the structure, and importance to the region's highly 508 complex water management system (Karaev, 2005; Kraak, 2012b). Previous studies 509 have evaluated aspects of TRMM for Kyrgyzstan and the wider region; others have 510 investigated the potential for seasonal forecasting of runoff for large basins in Central 
511 Asia. We refined these analyses by showing how predictive skill might be maximised

512 through judicious selection of TRMM cell(s), averaging and lag intervals.

513 Despite the simplicity of the models and limited data requirements over $80 \%$ of the 514 variance in monthly inflows is explained with three month lead, and up to $65 \%$ for 515 summer half-year flows based on TRMM estimates of winter precipitation. In line with 516 earlier research, temperature was found to have limited predictive skill at monthly 517 scales, and no skill for seasonal forecasting Naryn flows. The sub-basin feeding the 518 major tributary below Song Kol Lake was shown to have significant influence on 519 inflows during the melt season and is a priority location for long-term monitoring. 520 Indeed, any remaining meteorological stations in the vicinity $\left(41^{\circ} 50^{\prime} \mathrm{N}, 75^{\circ} 10^{\prime} \mathrm{E}\right)$ 521 should be protected from closure, and the area prioritised for network expansion.

522 Despite the parsimony of the regression models there may be good reasons for 523 parallel development of non-linear statistical or deterministic algorithms (such as the 524 Snowmelt Runoff Model (SRM) which has already been implemented for the Naryn 525 basin) (Wilby et al., 2011). These models could assimilate remotely sensed snow 526 cover for initialising forecasts of runoff over days to weeks ahead, driven by 527 numerical weather predictions of precipitation and temperature. In this way, 528 probabilistic forecasts of extreme inflows could be issued by deploying ensemble 529 predictions of inputs and SRM parameter sets. Snow and ice budgeting can also be 530 used to carry-over mass balance changes between successive melt seasons and to 531 investigate the observed long-term deglacierization of the Naryn due to prolongation 532 of the melt season (Kriegel et al., 2013).

533 We demonstrated the possibility of forecasting reservoir inflows using TRMM 534 precipitation estimates but the approach remains the same regardless of the satellite 535 products employed. Key steps include evaluating precipitation estimates against 536 available surface data at various time and space scales, then selecting those parts of 537 the river basin that yield greatest predictability for specified forecast horizons. 538 Credibility of the statistical model(s) is strengthened where physically sensible 539 explanations can be given for the prediction skill, and when stationarity of model 540 parameters has been tested through cross-validation techniques. Although the 541 TRMM satellite is expected to cease operating in February 2016 the successor 
542 and/or other precipitation estimates could be calibrated then used in operational flow 543 forecasts for strategically important water infrastructure in Central Asia.

544 Finally, beyond river flow, other environmental hazards affecting reservoir operations 545 may be predictable from satellite products. For instance, peak occurrence for 546 landslides and mudflows tends to be associated with rising temperatures and heavy 547 rainfall in spring. This opens the potential for predicting rainfall-triggered landslides 548 (including mud and debris flows) from real-time satellite imagery (as in Hong et al., 549 2006; 2007b; 2007c). The Goddard Space Flight Center already provides global 550 maps of potential landslide areas based on rainfall estimates with 1, 3 and 7 day 551 lead time ${ }^{3}$. Potential contingency measures that could be taken at individual 552 hydropower plants include draw down of reservoir level to increase freeboard for 553 flood waves induced by channel blockage or debris slides.

554

555 Acknowledgements

556 Observed rainfall and river flow data were provided by the Kyrgyzstan Ministry of 557 Water Resources and Tajik Hydromet through the Pilot Programme for Climate 558 Resilience (PPCR) with the support of the European Bank for Reconstruction and 559 Development (EBRD). The authors are grateful for the insightful suggestions made 560 by Nasridin Minikulov and two anonymous referees.

\footnotetext{
${ }^{3}$ http://trmm.gsfc.nasa.gov/publications dir/potential landslide.html
} 


\section{References}

562 Adler, R.F. Huffman, G.J., Chang, A., Ferraro, R., Xie, P.P., Janowiak, J., Rudolf, B.,

563 Schneider, U., Curtis, S., Bolvin, D., Gruber, A., Susskind, J., Arkin, P. and Nelkin, E.

564 (2003). The Version-2 Global Precipitation Climatology Project (GPCP) Monthly

565 Precipitation Analysis (1979-Present). Journal of Hydrometeorology, 4 (6), 1147-

5661167.

567 Aizen, E.M., Aizen, V.B., Melack, J.M., Nakamura, T. and Ohta, T. (2001).

568 Precipitation and atmospheric circulation patterns at mid-latitudes of Asia.

569 International Journal of Climatology, 21, 535-556.

570 Aizen, V.B., Aizen, E.M and Melack, J.M. (1995a). Climate, snow cover, glaciers and

571 runoff in the Tien Shan, Central Asia. Water Resources Bulletin, 31 (6), 1113-1129.

572 Aizen, V.B., Aizen, E.M. and Melack, J.M. (1995b). Characteristics of runoff

573 formation at the Kirgizskiy Alatoo. Proceedings of a boulder Symposium (IAHS

574 Publications). 228, 413-430.

575 Aizen, V.B., Aizen, E.M and Melack, J.M. (1996). Precipitation, melt and runoff in the 576 northern Tien Shan. Journal of Hydrology, 186, 229-251.

577 Aizen, V.B., Aizen, E.M., Melack, J.M. and Dozier, J. (1997). Climate change

578 impacts on glaciers and runoff in Tien Shan (Central Asia).Journal of Climate, 10 (6), 579 1393-1404.

580 Archer, D.R. and Fowler, H.J. 2008. Using meteorological data to forecast seasonal

581 runoff on the River Jhelum, Pakistan. Journal of Hydrology, 361, 10-23.

582 Artan, G. Gadain, H., Smith, J.L., Asante, K., Bandaragoda, C.J. and Verdin, J.P. 583 (2007). Adequacy of satellite derived rainfall data for stream flow modeling. Natural 584 Hazards, 43, 167-185.

585 Balthrop, C. and Hossain, F. (2010). Short note: A review of state of the art on 586 treaties in relation to management of transboundary flooding in international river 587 basins and the Global Precipitation Measurement mission. Water Policy, 12, 635588640. 
589 Barros, A.P., Kim, G., Williams, E. and Nesbitt, S.W. (2004). Probing orographic 590 controls in the Himalayas during the monsoon using satellite imagery. Natural 591 Hazards and Earth System Sciences, 4, 29-51.

592 Bell, T.L. and Kundu, P.K. (2003). Comparing satellite rainfall estimates with rain 593 gauge data: Optimal strategies suggested by a spectral model. Journal of 594 Geophysical Research: Atmospheres, 108, 4121.

595 Berg, W., L'Ecuyer, T. and Kummerow, C. (2006). Rainfall Climate Regimes: The 596 Relationship of Regional TRMM Rainfall Biases to the Environment. Journal of 597 Applied Meteorology and Climatology, 45, 434-454.

598 Bitew, M.M., Gebremichael, M., Ghebremichael, L.T. and Bayissa, Y.A. (2012).

599 Evaluation of High-Resolution Satellite Rainfall Products through Streamflow 600 Simulation in a Hydrological Modeling of a Small Mountainous Watershed in 601 Ethiopia. Journal of Hydrometeorology, 13, 338-350.

602 Bookhagen, B. and Burbank, D.W. (2010). Toward a complete Himalayan 603 hydrological budget: Spatiotemporal distribution of snowmelt and rainfall and their 604 impact on river discharge. Journal of Geophysical Research, 116, 1-25.

605 Bothe, O., Fraedrich, K. and Zhu, X. (2012). Precipitation climate of Central Asia and 606 the large-scale atmospheric circulation. Theoretical and Applied Climatology, 108 (3607 4), 345-354.

608 Bowman, K.P. (2004). Comparison of TRMM precipitation retrievals with rain gauge 609 data from ocean buoys. Journal of Climate, 18, 178-190.

610 Chintalapudi, S., Sharif, H.O., Yeggina, S. and Elhassan, A. (2012). Physically 611 based, hydrologic model results based on three precipitation products. Journal of the 612 American Water Resources Association, 48 (6), 1191-1203.

613 Collischonn, B. and Pante, A.R. (2011). TRMM-forced rainfall-runoff modelling for 614 water management purposes in small ungauged basins. IAHS-AISH publication. 615 ISSN- 0144-7815. 
616 Condom, T., Rau, P. and Espinoza, J.C. (2011). Correction of TRMM 3B43 monthly

617 precipitation data over the mountainous areas of Peru during the period 1998-

618 2007. Hydrological Processes, 25, 1924-1933.

619 Dawson, C.W., Abrahart, R.J. and See, L.M. 2007. HydroTest: A web-based toolbox 620 of evaluation metrics for the standardised assessment of hydrological forecasts.

621 Environmental Modelling and Software, 22, 1034-1052.

622 Ebert, E.E., Janowiak, J.E. and Kidd, C. (2007). Comparison of Near-Real-Time 623 Precipitation Estimates from Satellite Observations and Numerical Models. American 624 Meteorological Society, 88, 47-64.

625 Gebremichael, M., Anagnostou, E.N. and Bitew, M.M. (2010). Critical Steps for 626 Continuing Advancement of Satellite Rainfall Applications for Surface Hydrology in 627 the Nile River Basin. Journal of the American Water Resources Association, 46, 361628366.

629 Hirpa, F.A., Hopson, T.M., De Groeve, T., Brakenridge, G.R., Gebremichael, M. and 630 Respreto, P.J. (2013). Upstream satellite remote sensing for river discharge 631 forecasting: Application to major rivers in South Asia. Remote Sensing of 632 Environment, 131, 140-151.

633 Hodgson, S. (2010). Strategic Water Resources in Central Asia: in search of a new 634 international legal order. Centre for European Policy Studies, Policy Brief No.14. 635 Madrid, Spain, 6pp.

636 Hong, Y., Adler, R. and Huffman, G. (2006). Evaluation of the potential of NASA 637 multi-satellite precipitation analysis in global landslide hazard assessment. 638 Geophysical Research Letters, 33, L22402.

639 Hong, Y., Adler, R.F., Hossain, F. Curtis, S. and Huffman, G.J. (2007a). A first 640 approach to global runoff simulation using satellite rainfall estimation. Water 641 Resources Research, 43, 1-8.

642 Hong, Y., Adler, R.F, Negri, A. and Huffman, G.J. (2007a). Flood and landslide 643 applications of near real-time satellite rainfall estimation. Natural Hazards, 43, 285644294. 
645 Hong, Y., Adler, R.F. and Huffman, G.J. (2007b). An experimental global monitoring 646 system for rainfall-triggered landslides using satellite remote sensing information.

647 IEEE Trans. on Geosciences and Remote Sensing, 45, 1671-1680.

648 Hopson, T.M. and Webster, P.J. (2010). A 1-10-Day Ensemble Forecasting Scheme 649 for the Major River Basins of Bangladesh: Forecasting Severe Floods of 2003-07. 650 Journal of Hydrometeorology, 11, 618-641.

651 Hossain, F., Katiyar, N., Wolf, A. and Hong, Y. (2007). The emerging role of satellite 652 rainfall data in improving the hydro-political situation of flood monitoring in the under653 developed regions of the world. Natural Hazards, 43 (2), 199-210.

654 Huffman, G.J. and Bolvin, D.T. (2013). TRMM and Other Data Precipitation Data Set 655 Documentation. Mesoscale Atmospheric Process Laboratory, NASA Goddard Space 656 Flight Center and Science Systems and Applications, Inc.

657 ftp://precip.gsfc.nasa.gov/pub/trmmdocs/3B42_3B43_doc.pdf. [Accessed 658 31/07/2013].

659 Huffman, G.J. Adler, R.F., Bolvin, D.T., Gu, G., Nelkin, E.J., Bowman, K.P., Hong, 660 Y., Stocker, E.F. and Wolff, D.B. (2007). The TRMM Multisatellite Precipitation 661 Analysis (TMPA): Quasi-Global, Multiyear, Combined-Sensor Precipitation Estimates 662 at Fine Scales. Journal of Hydrometeorology, 8, 38-55.

663 Hughes, D.A. (2006). Comparison of satellite rainfall data with observations from 664 gauging station networks. Journal of Hydrology, 327, 399-410.

665 Immerzeel, W.W., Lutz, A.F. and Droogers, P. (2012). Climate Change Impacts on 666 the Upstream Water Resources of the Amu and Syr Darya River Basins. 667 Wageningen, The Netherlands.

668 Immerzeel, W.W., van Beek, L.P.H. and Bierkens, M.F.P. (2010). Climate Change 669 Will Affect the Asian Water Towers. Science, 328, 1382-1385.

670 Ismaiylov, G.K., Federov, V.M. and Sadati Nezhad, S.D. (2007). Assessment of 671 possible anthropogenic changes in the runoff of the Syr Darya River on the basis of 672 a mathematical model. Water Resources, 34 (4), 359-371. 
$673 \mathrm{Ji}, \mathrm{X}$. and Chen, Y. (2012). Characterizing spatial patterns of precipitation based on 674 corrected TRMM 3B43 data over the mid Tianshan Mountains of China. Journal of 675 Mountain Science, 9 (5), 628-645.

$676 \mathrm{Ji}, \mathrm{X}$. and Yu, Y. (2013). The influence of precipitation and temperature input 677 schemes on hydrological simulations of a snow and glacier melt dominated basin in 678 Northwest China. Hydrology and Earth System Sciences Discussion Paper, 10, 807679853.

680 Karaev, Z. (2005). Water diplomacy in Central Asia. Middle East Review of 681 International Affairs, 9 (1), 63-69.

682 Karaseva, M.O., Prakash, S. and Gairola, R.M. (2012). Validation of high-resolution 683 TRMM-3B43 precipitation product using rain gauge measurements over 684 Kyrgyzstan. Theoretical and Applied Climatology, 108, 147-157.

685 Kekete, B.M., Vorosmarty, C.J., Roads, J.O. and Willmott, C.J. (2004). Uncertainties 686 in precipitation and their impact on runoff estimates. Journal of Climate, 17, 294-304.

687 Kraak, E. (2012a). Central Asia's dam debacle. Available:

$688 \mathrm{http} / /$ www.chinadialogue.net/article/show/single/en/4790-Central-Asia-s-dam689 debacle. [Accessed 07/12/2013].

690 Kraak, E. (2012b). The Geopolitics of Hydropower in Central Asia: the Syr 691 Darya. The Asia-Pacific Journal, 105 (15).

692 Kriegel, D. Mayer, C., Hagg, W., Vorogushyn, S., Duethmann, D., Gafurov, A. and 693 Farinotti, D. (2013). Changes in glacierisation, climate and runoff in the second half 694 of the 20th century in the Naryn basin, Central Asia. Global and Planetary Change, $695110,51-61$.

696 Magar, R.B. and Jothiprakash, V. (2011). Intermittent reservoir daily-inflow prediction 697 using lumped and distributed data multi-linear regression models. Journal of Earth 698 Systems Science, 120 (6), 1067-1084.

699 Matzler, C. and Standley, A. (2000). Relief effects for passive microwave remote 700 sensing. International Journal of Remote Sensing, 21, 2403-2412. 
701 Milewski, A. Sultan, M., Yan, E., Becker, R., Abdeldayem, A., Soliman, F. and Gelil, 702 K.A. (2009). A remote sensing solution for estimating runoff and recharge in arid 703 environments. Journal of Hydrology, 373, 1-14.

704 NASA. (2011). TRMM Senior Review Proposal. Available:

705 http://pmm.nasa.gov/sites/default/files/document_files/TRMMSenRevProp_v1.2.pdf. 706 [Accessed 31/07/2013].

707 Pal, I., Lall, U., Robertson, A.W., Cane, M.A. and Bansal, R. (2013). Predictability of 708 Western Himalayan river flow: melt season inflow to Bhakra Reservoir in northern 709 India. Hydrology and Earth System Sciences, 17, 2131-2146.

710 Pereira-Cardenal, S.J., Riegels, N.D., Berry, P.A.M., Smith, R.D., Yakovlev, A., 711 Siegfried, T.U. and Bauer-Gottwein, P. (2011). Real-time remote sensing driven river 712 basin modeling using radar altimetry. Hydrology and Earth System Sciences, 15, 713 241-254.

714 Petty, G.W. (2001). Physical and Microwave Radiative Properties of Precipitation 715 Clouds. Part II: A Parametric 1D Rain-Cloud Model for Use in Microwave Radiative 716 Transfer Simulations. Journal of Applied Meteorology, 40, 2115-2129.

717 Raskin, P., Hansen, E., Zhu, Z. and Stavisky, D. (1992). Simulation of Water Supply 718 and Demand in the Aral Sea Region. Water International, 17, 55-67.

719 Sagintayev, Z. Sultan, M., Khan, S.D., Khan, S.A., Mahmood, K., Yan, E., Milewski, 720 A. and Marsala, P. (2012). A remote sensing contribution to hydrologic modelling in 721 arid and inaccessible watersheds, Pishin Lora basin, Pakistan. Hydrological 722 Processes, 26 (1), 85-99.

723 Savoskul, O., Chevnina, E.V., Perziger, F.I., Vasilina, L.Y., Baburin, V.L., Danshin, 724 A.I., Matyakubov, B. and Murakaev, R.R. (2003). Water, climate, food, and 725 environment in the Syr Darya Basin, in Adaptation Strategies to Changing 726 Environments, Institute for Environmental Studies. Vrije University., Amsterdam.

727 Schär, C., Vasilina, L., Pertziger, F. and Dirren, S. (2004). Seasonal runoff 728 forecasting using precipitation from meteorological data assimilation systems. 729 Journal of Hydrometeorology, 5, 959-973. 
730 Scheel, M.L.M. Rohrer, M., Huggel, C., Santos Villar, D., Silvestre, E. and Huffman,

731 G.J. (2011). Evaluation of TRMM Multi-satellite Precipitation Analysis (TMPA)

732 performance in the Central Andes region and its dependency on spatial and

733 temporal resolution. Hydrology and Earth System Sciences, 15, 2649-2663.

734 Schiemann, R., Glazirina, M.G. and Schär, C. (2007). On the relationship between

735 the Indian summer monsoon and river flow in the Aral Sea basin. Geophysical

736 Research Letters, 34, L05706.

737 Siegfried, T. Bernauer, T., Guiennet, R., Sellars, S., Robertson, A.W., Mankin, J.,

738 Bauer-Gottwein, P. and Yakovlev, A. (2012). Will climate change exacerbate water

739 stress in Central Asia? Climate Change, 112, 881-889.

740 Sorg, A., Bolch, T., Stoffel, M., Solomina, O., and Beniston, M. (2012). Climate

741 change impacts on glaciers and runoff in the Tien Shan (Central Asia). Nature

742 Climate Change, 2, 725-731.

743 Stisen, S. and Sandholt, I. (2010). Evaluation of remote-sensing-based rainfall

744 products through predictive capability in hydrological runoff modelling. Hydrological

745 Processes, 24 (7), 879-891.

746 Su, F., Hong, Y. and Lettermaier, D.P. (2008). Evaluation of TRMM Multisatellite

747 Precipitation Analysis (TMPA) and Its Utility in Hydrologic Prediction in the La Plata

748 Basin. Journal of Hydrometeorology, 9, 622-640.

749 Umaraliev, T. (2012). Kyrgyzstan has energy crisis during very cold winter. Available:

750 http://www.washingtontimes.com/news/2012/jan/27/kyrgyzstan-has-energy-crisis-

751 during-very-cold-wint/?page=all. [Accessed 20/07/2013].

752 UNDP. (2012). Natural Disaster Risks in Central Asia. Available:

753 http://europeandcis.undp.org/uploads/public1/files/vulnerability/Senior\%20Economist

754 \%20Web\%20site/Policy\%20brief_Natural\%20Disaster\%20Risks\%20in\%20Central\%

755 20Asia.pdf. [Accessed 18/07/2013].

756 UNEP. (2008). The disappearance of the Aral Sea. In: Diop, S. and Rekacewicz,

757 P. Vital Water Graphics - An Overview of the State of the World's Fresh and Marine

758 Waters. 2nd ed. Nairobi, Kenya: UNEP. 
759 Wilby, R.L. and Yu, D. (2013). Rainfall and temperature estimation for a data sparse 760 region. Hydrology and Earth System Sciences, 17, 3937-3955.

761 Wilby, R.L., Minikulov, N. and Rabb, B. (2011). ANNEX 1: Modelling the climate762 sensitivity of rivers entering the Kairakkum and Nurek reservoirs, Tajikistan.

763 Available: http://www.ppcr.tj/IP/Phase1/Component4/Annex\%201.pdf. [Accessed 764 31/07/2013].

765 Yilmaz, K.K. et al. (2005). Intercomparison of Rain Gauge, Radar, and Satellite766 Based Precipitation Estimates with Emphasis on Hydrologic Forecasting. Journal of 767 Hydrometeorology, 6 (4), 497-517.

768 Yong, B. Hong, Y., Ren, L., Gourley, J., Huffman, G.J., Chen, X., Wang, W. and 769 Khan, S.I. (2012). Assessment of evolving TRMM-based multisatellite real-time 770 precipitation estimation methods and their impacts on hydrologic prediction in a high 771 latitude basin. Journal of Geophysical Research, 117, 1-21.

772 Yu, M., Chen, X., Li, L., Boa, A. and Jean de la Paix, M. (2011). Streamflow 773 Simulation by SWAT Using Different Precipitation Sources in Large Arid Basins with 774 Scarce Raingauges. Water Resources Management, 25, 2669-2681. 
775 Table 1 Variables used in regression models

\begin{tabular}{|c|l|}
\hline $\mathrm{P}_{\mathrm{t}, \mathrm{n}}$ & Naryn meteorological station precipitation \\
\hline $\mathrm{PA}_{\mathrm{t}, \mathrm{n}}$ & $0.5^{\circ}$ TRMM area average precipitation estimate \\
\hline $\mathrm{PO}_{\mathrm{t}, \mathrm{n}}$ & $0.5^{\circ}$ TRMM optimum cell precipitation estimate \\
\hline $\mathrm{T}_{\mathrm{t}, \mathrm{n}}$ & Naryn meteorological station temperature \\
\hline $\mathrm{Q}_{\mathrm{t}, \mathrm{n}}$ & Discharge at Toktogul \\
\hline $\mathrm{t}$ & Variable lag interval ( $t$ months $)$ \\
\hline $\mathrm{n}$ & Variable averaging period $(n$ months) \\
\hline $\mathrm{M}$ & Dummy variable for each calendar month $(0$ or 1$)$ \\
\hline
\end{tabular}

776

777

778

779

780 Table 2 Statistical estimates of the intercepts $(\alpha)$ and parameters $(\beta)$ of simple linear

781 regression models, along with the amount of explained variance $\left(R^{2}\right.$ adj $)$, standard

782 error (SE) of the summer (April to September) runoff estimate $\left(\mathrm{m}^{3} \mathrm{~s}^{-1}\right)$ and model

783 significance level $(p)$. All predictors except for time are for the winter half-year

784 (October to March).

\begin{tabular}{|l|l|l|l|l|l|}
\hline Predictor & $\boldsymbol{\alpha}\left(\mathbf{m}^{\mathbf{3}} \mathbf{s}^{-1}\right)$ & $\boldsymbol{\beta}$ & $\left.\mathbf{R}_{\text {adj }}^{\mathbf{2}} \mathbf{\%}\right)$ & $\mathbf{S E}\left(\mathbf{m}^{\mathbf{3}} \mathbf{s}^{-1}\right)$ & $\boldsymbol{p}$ value \\
\hline Time (year) & 22993 & -11.14 & 0 & 123 & 0.437 \\
\hline T & 525 & -28.83 & 0 & 123 & 0.418 \\
\hline P & 473 & 12.67 & 22 & 107 & 0.096 \\
\hline PA & 197 & 16.81 & 50 & 86 & 0.013 \\
\hline PO & 247 & 17.85 & 65 & 71 & 0.003 \\
\hline Q & 151 & 2.44 & 18 & 110 & 0.123 \\
\hline
\end{tabular}


786 Table 3 Summary of regression model predictor variables, explained variance $\left(R^{2}{ }_{\text {adj }}\right)$ 787 and standard errors (SE) by forecast horizon ( $t+0$ to $t+3$ months). In each case, the 788 final predictor set is shown in bold italics. See Table 1 for notations.

\begin{tabular}{|c|c|c|c|}
\hline Model & Predictors & $\mathrm{R}_{\text {adj }}^{2}(\%)$ & $S E\left(m^{3} s^{-1}\right)$ \\
\hline ZOF & $M$ & 81 & 147 \\
\hline \multirow[t]{9}{*}{$\mathrm{Q} 0(\mathrm{t}+0)$} & $\mathrm{PA}_{0,4}$ & 42 & 258 \\
\hline & $T_{0,1}$ & 53 & 232 \\
\hline & $\mathrm{P}_{0,3}$ & 54 & 228 \\
\hline & $\mathrm{Q}_{1,1}$ & 59 & 217 \\
\hline & $\mathrm{PO}_{0,4}$ & 73 & 174 \\
\hline & $\mathrm{Q}_{1,1}, \mathrm{PO}_{0,4}$ & 81 & 145 \\
\hline & $\mathrm{Q}_{1,1}, \mathrm{PO}_{0,4}, \mathrm{~T}_{0,1}$ & 84 & 137 \\
\hline & $M, Q_{1,1}, P_{0,4}, T_{0,1}$ & 90 & 109 \\
\hline & $M, Q_{1,1}, P O_{0,4}^{*}$ & 90 & 109 \\
\hline \multirow[t]{9}{*}{ Q1 (t+1) } & $\mathrm{T}_{1,1}$ & 35 & 273 \\
\hline & $P_{1,1}$ & 37 & 268 \\
\hline & $P_{1,2}$ & 44 & 252 \\
\hline & $\mathrm{PA}_{1,2}$ & 51 & 235 \\
\hline & $\mathrm{PO}_{1,3}$ & 64 & 203 \\
\hline & $\mathrm{Q}_{1,1}, \mathrm{PO}_{1,3}$ & 70 & 185 \\
\hline & $\mathrm{Q}_{1,1}, \mathrm{PO}_{1,3}, \mathrm{~T}_{1,1}$ & 71 & 183 \\
\hline & $M, Q_{1,1}, P_{1,3}$ & 89 & 111 \\
\hline & $M, Q_{1,1}, P O_{1,3}{ }^{*}, T_{1,1}$ & 89 & 110 \\
\hline \multirow[t]{8}{*}{ Q2 (t+2) } & $\mathrm{T}_{2,1}$ & 9 & 322 \\
\hline & $Q_{2,1}$ & 10 & 319 \\
\hline & $P_{2,1}$ & 30 & 283 \\
\hline & $\mathrm{PA}_{2,1}$ & 43 & 254 \\
\hline & $\mathrm{PO}_{2,1}$ & 48 & 242 \\
\hline & $\mathrm{Q}_{2,1}, \mathrm{PO}_{2,1}, \mathrm{~T}_{2,1}$ & 50 & 239 \\
\hline & $\mathrm{Q}_{2,1}, \mathrm{PO}_{2,1}$ & 49 & 240 \\
\hline & $M, Q_{2,1}, P O_{2,1}{ }^{*}$ & 85 & 132 \\
\hline \multirow[t]{6}{*}{ Q3 $(t+3)$} & $\mathrm{T}_{3,1}$ & 1 & 336 \\
\hline & $Q_{3,1}$ & 1 & 336 \\
\hline & $P_{3,1}$ & 7 & 325 \\
\hline & $\mathrm{PA}_{3,1}$ & 14 & 313 \\
\hline & $\mathrm{PO}_{3,1}$ & 30 & 282 \\
\hline & $M, P O_{3,1} * *$ & 84 & 136 \\
\hline
\end{tabular}


790 Table 4 Predictor variables and regression model parameters for monthly flow 791 forecast models Q0, Q1, Q2 and Q3 based on available data (May 1999 to July 792 2010). Model parameters shown in bold are statistically significant $(p<0.05)$. Note 793 that the value of the dummy variable depends on prevailing month and may be 794 interpreted as the flow anomaly with respect to December (value zero).

\begin{tabular}{|l|r|r|r|r|}
\hline Variable & Q0 & Q1 & Q2 & Q3 \\
\hline Intercept & -121.93 & -69.29 & -39.78 & $\mathbf{1 4 9 . 7 5}$ \\
\hline Jan & -1.26 & -114.16 & 22.63 & $\mathbf{- 1 3 4 . 5 7}$ \\
\hline Feb & 32.71 & -119.44 & 53.88 & $-\mathbf{1 2 9 . 3 7}$ \\
\hline Mar & 64.44 & -20.24 & 109.82 & -79.16 \\
\hline Apr & $\mathbf{1 4 7 . 0 1}$ & $\mathbf{2 1 4 . 5 0}$ & $\mathbf{2 7 2 . 6 5}$ & 86.94 \\
\hline May & $\mathbf{3 4 8 . 5 3}$ & $\mathbf{5 4 6 . 2 6}$ & $\mathbf{5 8 0 . 5 9}$ & $\mathbf{4 6 0 . 6 7}$ \\
\hline Jun & $\mathbf{4 5 5 . 4 8}$ & $\mathbf{6 5 9 . 1 8}$ & $\mathbf{7 7 1 . 2 1}$ & $\mathbf{7 2 8 . 3 7}$ \\
\hline Jul & $\mathbf{1 8 5 . 6 4}$ & $\mathbf{3 9 9 . 0 2}$ & $\mathbf{4 7 7 . 5 0}$ & $\mathbf{5 3 0 . 4 5}$ \\
\hline Aug & 62.43 & $\mathbf{2 6 3 . 1 5}$ & $\mathbf{2 1 8 . 8 7}$ & $\mathbf{2 8 4 . 0 5}$ \\
\hline Sep & 16.53 & 215.15 & 31.27 & $\mathbf{1 4 7 . 8 3}$ \\
\hline $\mathrm{Oct}$ & 15.35 & $\mathbf{1 9 8 . 8 1}$ & 40.84 & $\mathbf{7 3 . 4 1}$ \\
\hline $\mathrm{Nov}$ & 15.86 & 109.27 & 57.99 & 56.92 \\
\hline $\mathrm{Q}_{1,1}$ & $\mathbf{0 . 4 8}$ & $\mathbf{0 . 5 0}$ & - & - \\
\hline $\mathrm{Q}_{2,1}$ & - & - & $\mathbf{0 . 3 5}$ & - \\
\hline $\mathrm{PO}_{0,4}$ & $\mathbf{4 . 0 6}$ & - & - & - \\
\hline $\mathrm{PO}_{1,3}$ & - & $\mathbf{2 . 5 4}$ & - & - \\
\hline $\mathrm{PO}_{2,1}$ & - & - & $\mathbf{1 . 9 5}$ & - \\
\hline $\mathrm{PO}_{3,1}$ & - & - & - & $\mathbf{2 . 3 1}$ \\
\hline $\mathrm{T}_{1,1}$ & $-\mathbf{1 0 . 9 0}$ & - & - \\
\hline
\end{tabular}

795 
796 Table 5 Cross-validation results for ZOF, Q1, Q2 and Q3 models

1

2

3

4

5

6

7

10

12

13

14

15

16

17

18

19

20

21

22

23

24

25

26

27

28

29

30

31

32

33

34

35

36

37

38

39

40

41

42

43

44

45

46

47

48

49

50

51

52

53

54

55

56

57

58

59

60

\begin{tabular}{|l|c|c|c|c|}
\hline Metric & ZOF & Q1 & Q2 & Q3 \\
\hline Root Mean Squared Error (RMSE) $\left(\mathrm{m}^{3} \mathrm{~s}^{-1}\right)$ & 151 & 118 & 139 & 144 \\
A Information Criteria (AIC) & 702 & 673 & 694 & 697 \\
Nash-Sutcliffe Coefficient (NSC) & 0.797 & 0.878 & 0.829 & 0.818 \\
Percentage Error in Peak (PEP) (\%) & -34.8 & -21.4 & -31.6 & -27.7 \\
Mean Absolute Relative Error (MARE) (\%) & 18.6 & 17.5 & 19.6 & 21.6 \\
\hline
\end{tabular}

797

798

799

URL: http://mc.manuscriptcentral.com/hsj 
800 Figure 1 a) Location of the River Naryn basin and Toktogul reservoir within 801 Kyrgyzstan; b) an elevation map of Kyrgyzstan.

802 a)

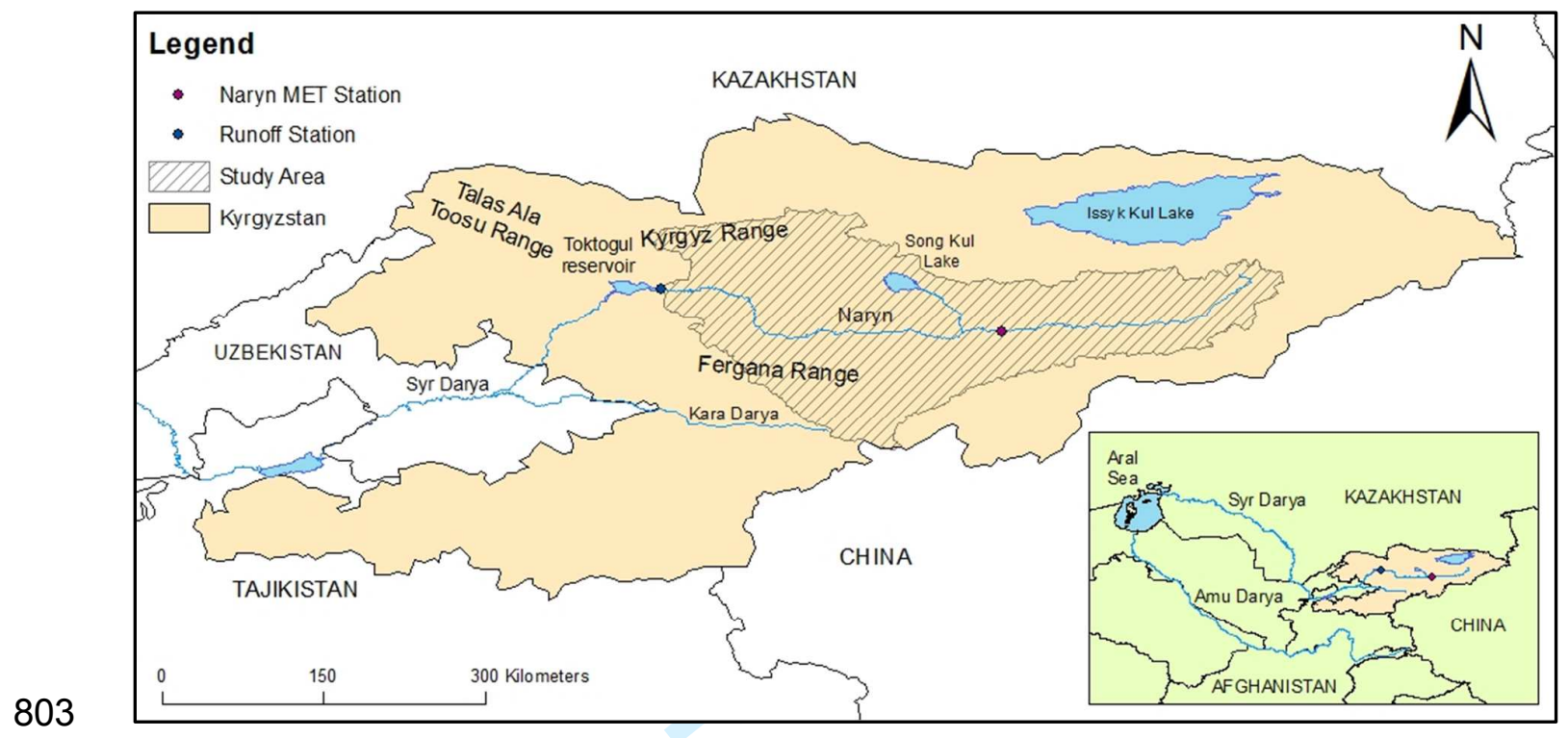

804 b)

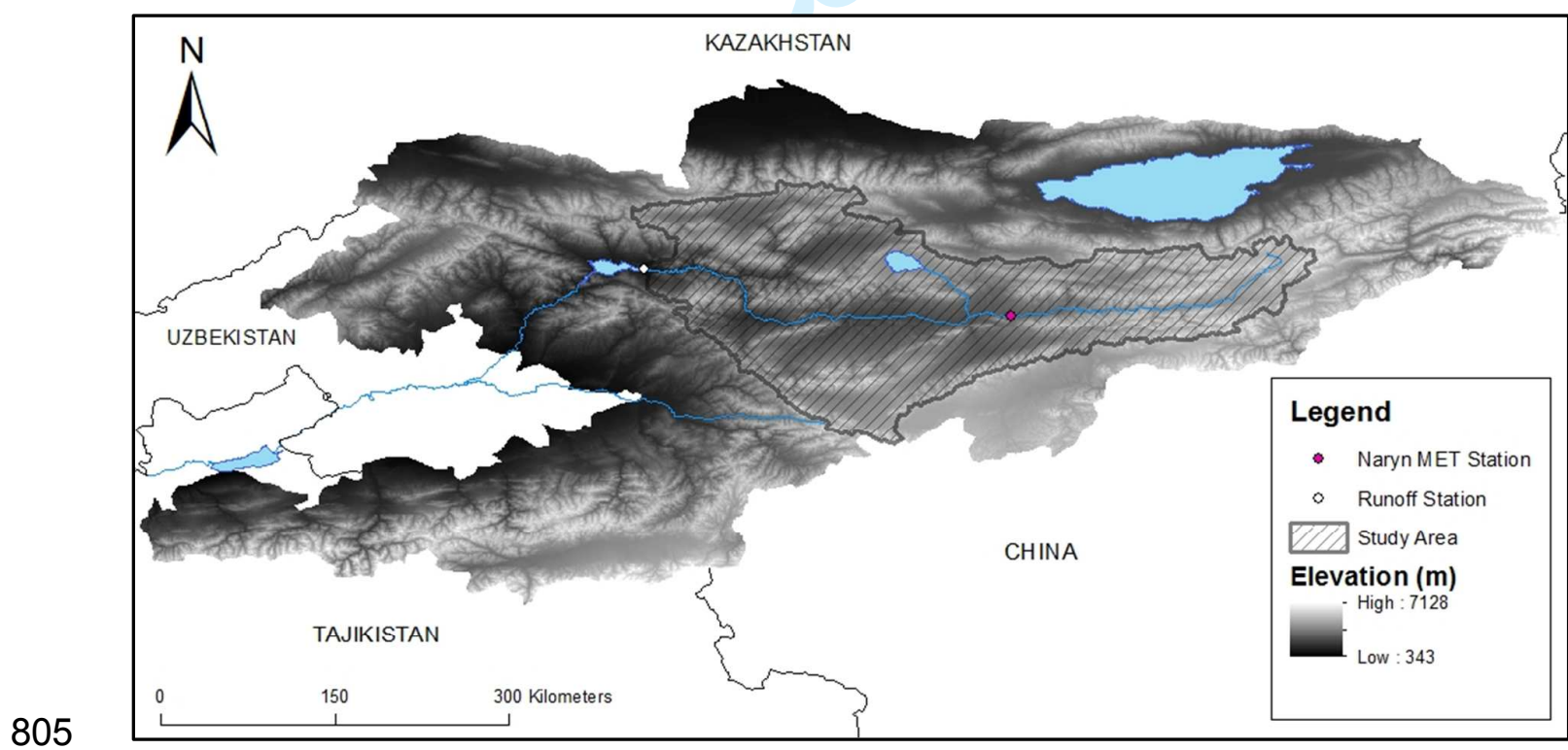

806

807

808

809

URL: http://mc.manuscriptcentral.com/hsj 
810 Figure 2 Number of GPCC gauges used by TRMM across the study area for 811 selected years. The location of the gauge at Naryn is shown by the red point.

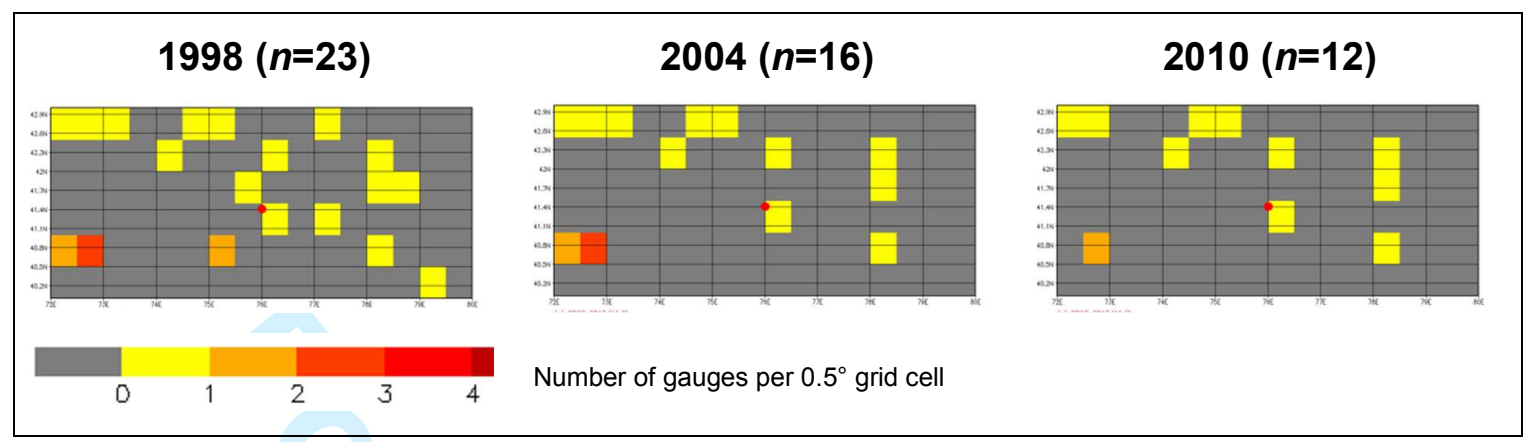

812

URL: http://mc.manuscriptcentral.com/hsj 
813 Figure 3 Gauge versus $0.5^{\circ}$ TRMM for a) monthly mean and b) annual precipitation 814 totals at Naryn 1998-2012.

815 a)

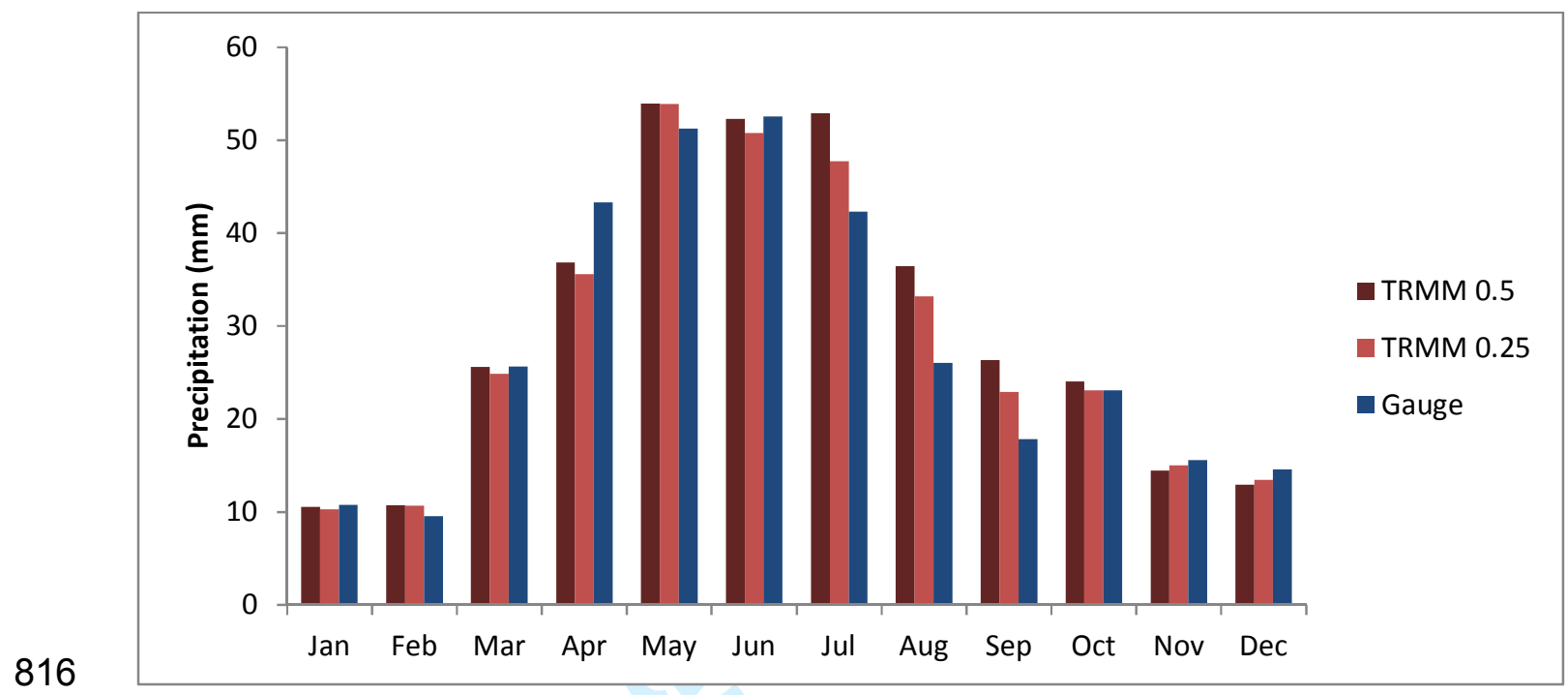

817 b)

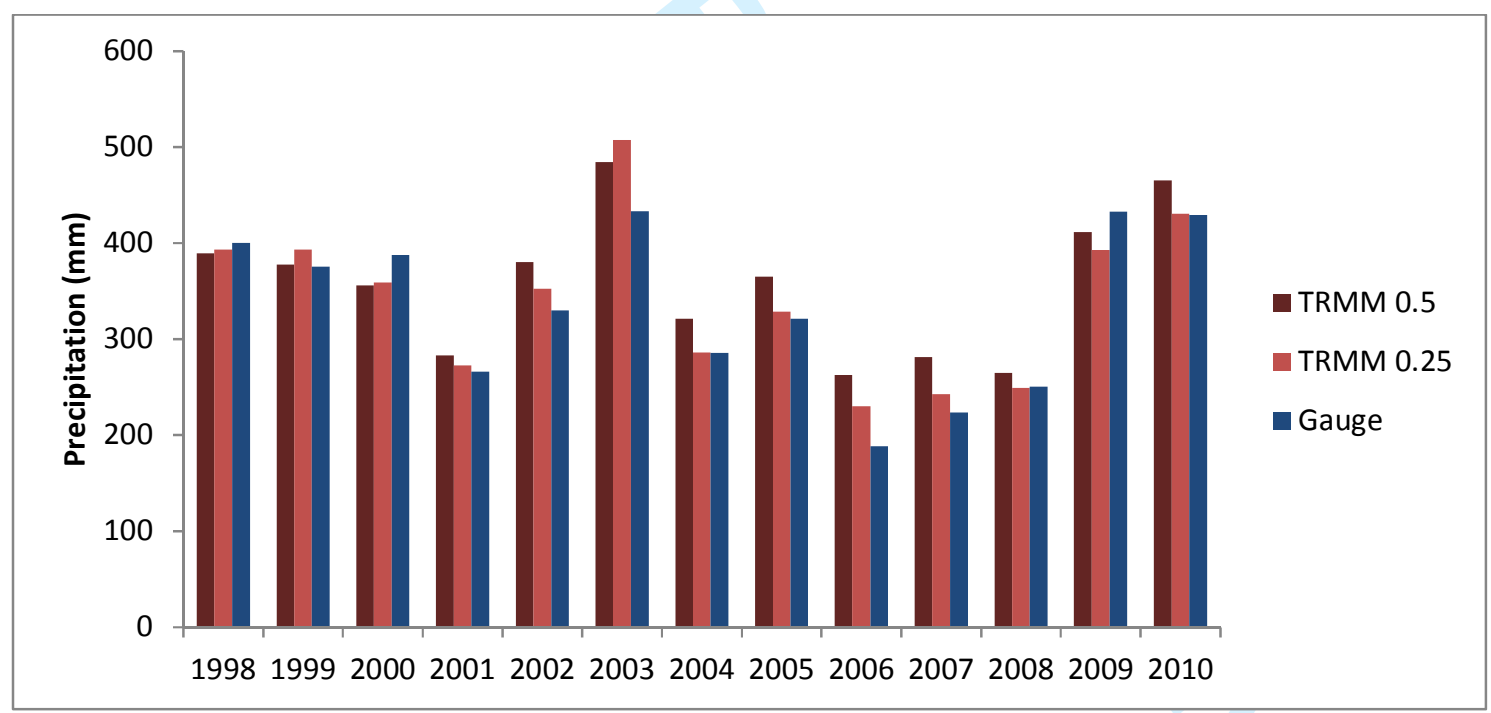

819 
820 Figure 4 Monthly total precipitation recorded by the gauge at Naryn compared with 821 the nearest a) $0.5^{\circ} \mathrm{TRMM}$ and b) $0.25^{\circ} \mathrm{TRMM}$ cell.

822 a)

823

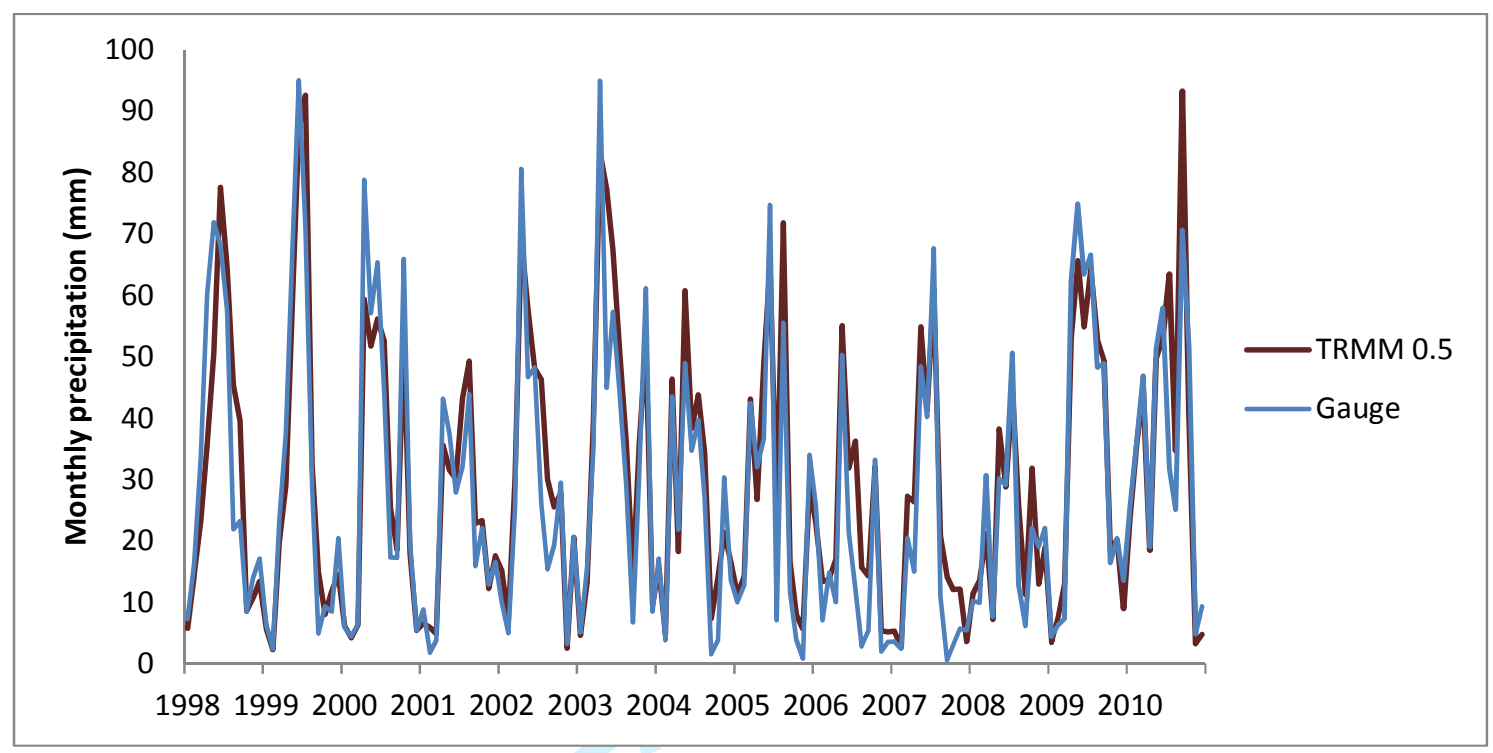

824

825 b)

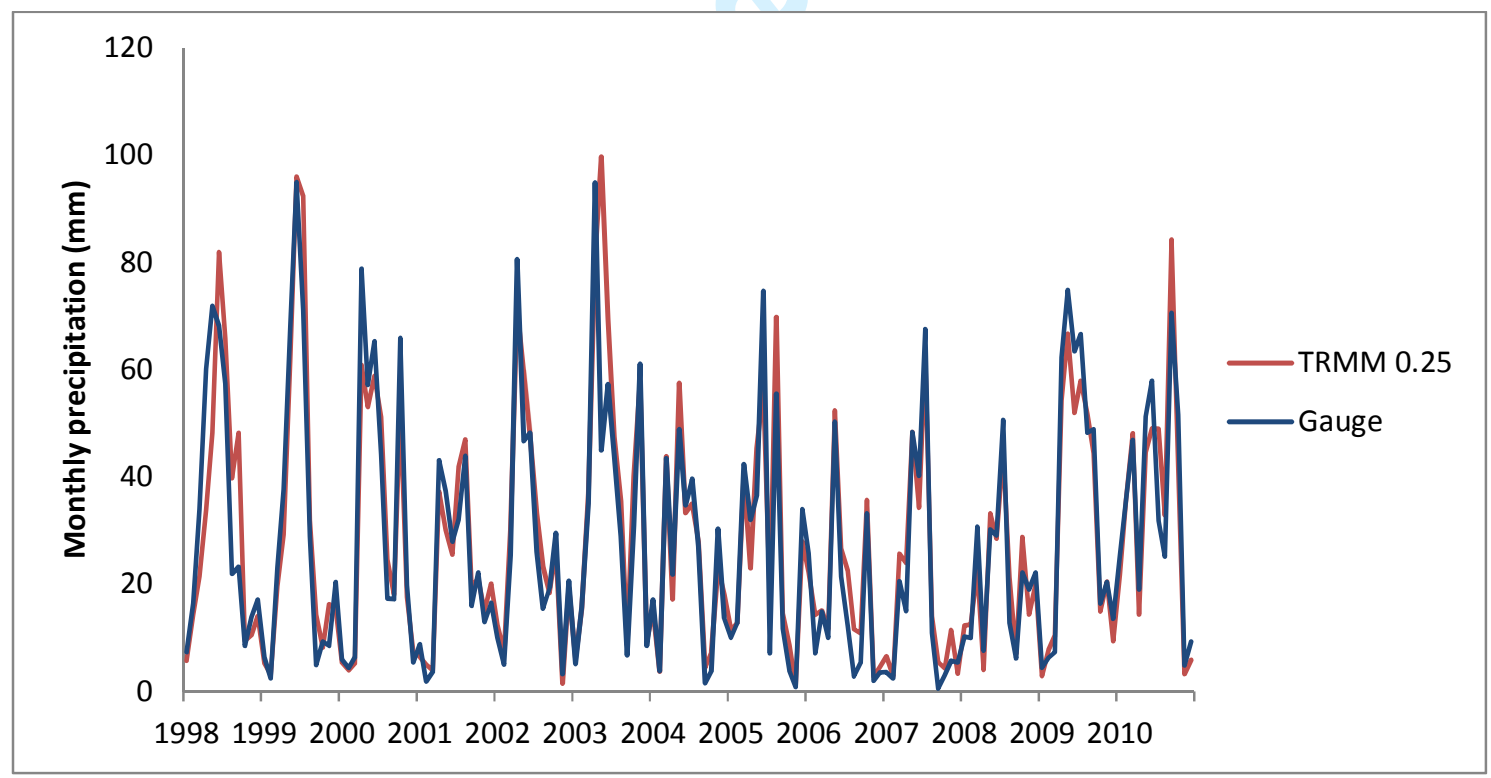

826
827

URL: http://mc.manuscriptcentral.com/hsj 
828 Figure 5 Cumulative monthly precipitation totals for Naryn meteorological station, 829 coincident $0.5^{\circ}$ TRMM and $0.25^{\circ}$ TRMM cells $1998-2010$.

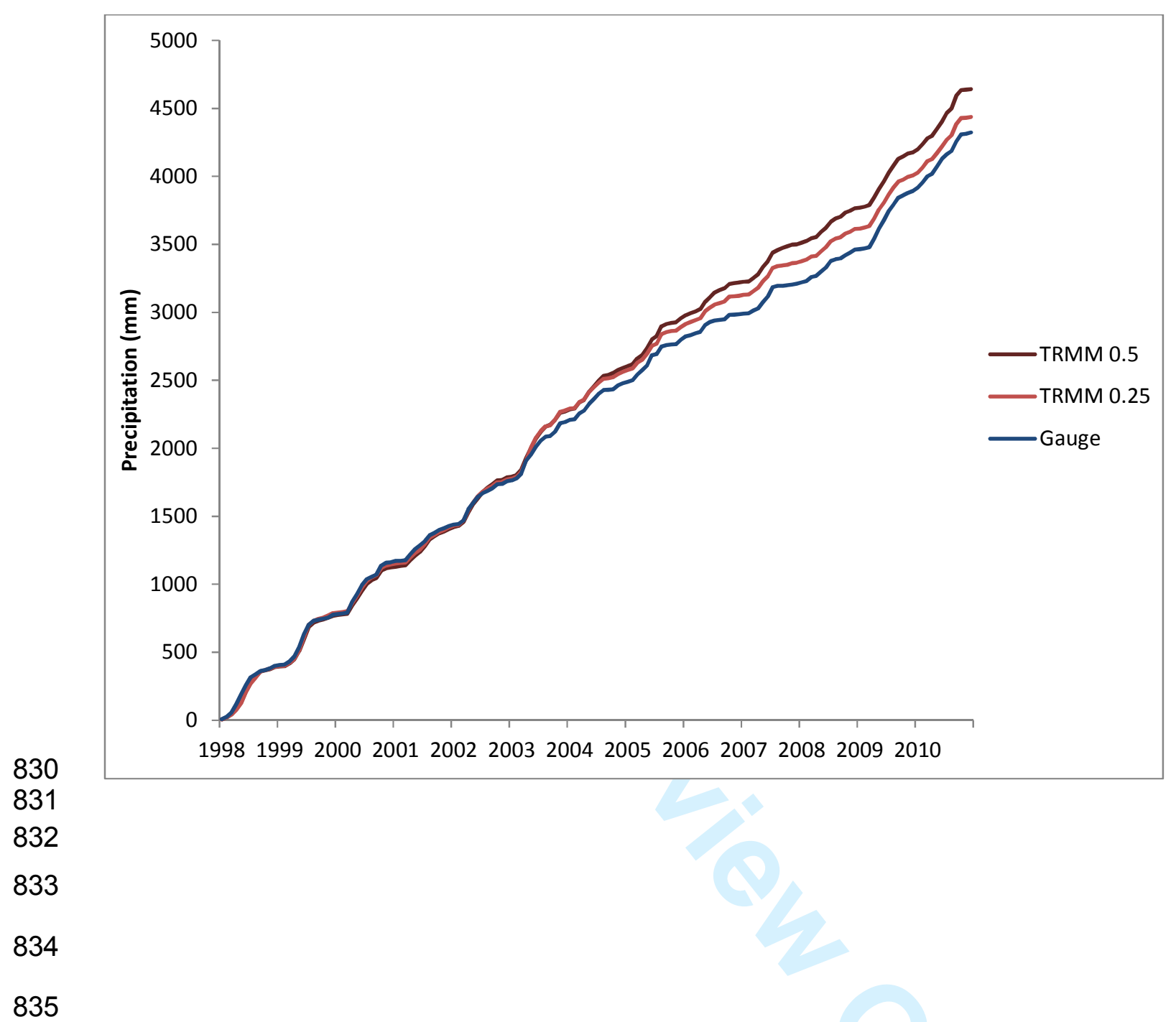

41

42

43

44

45

46

47

48

49

50

51

52

53

54

55

56

57

58

59

60

URL: http://mc.manuscriptcentral.com/hsj 
836 Figure 6 Cumulative percentile distributions of gauged, $0.5^{\circ} \mathrm{TRMM}$ and $0.25^{\circ} \mathrm{TRMM}$ 837 daily precipitation amounts at Naryn 1998-2012.

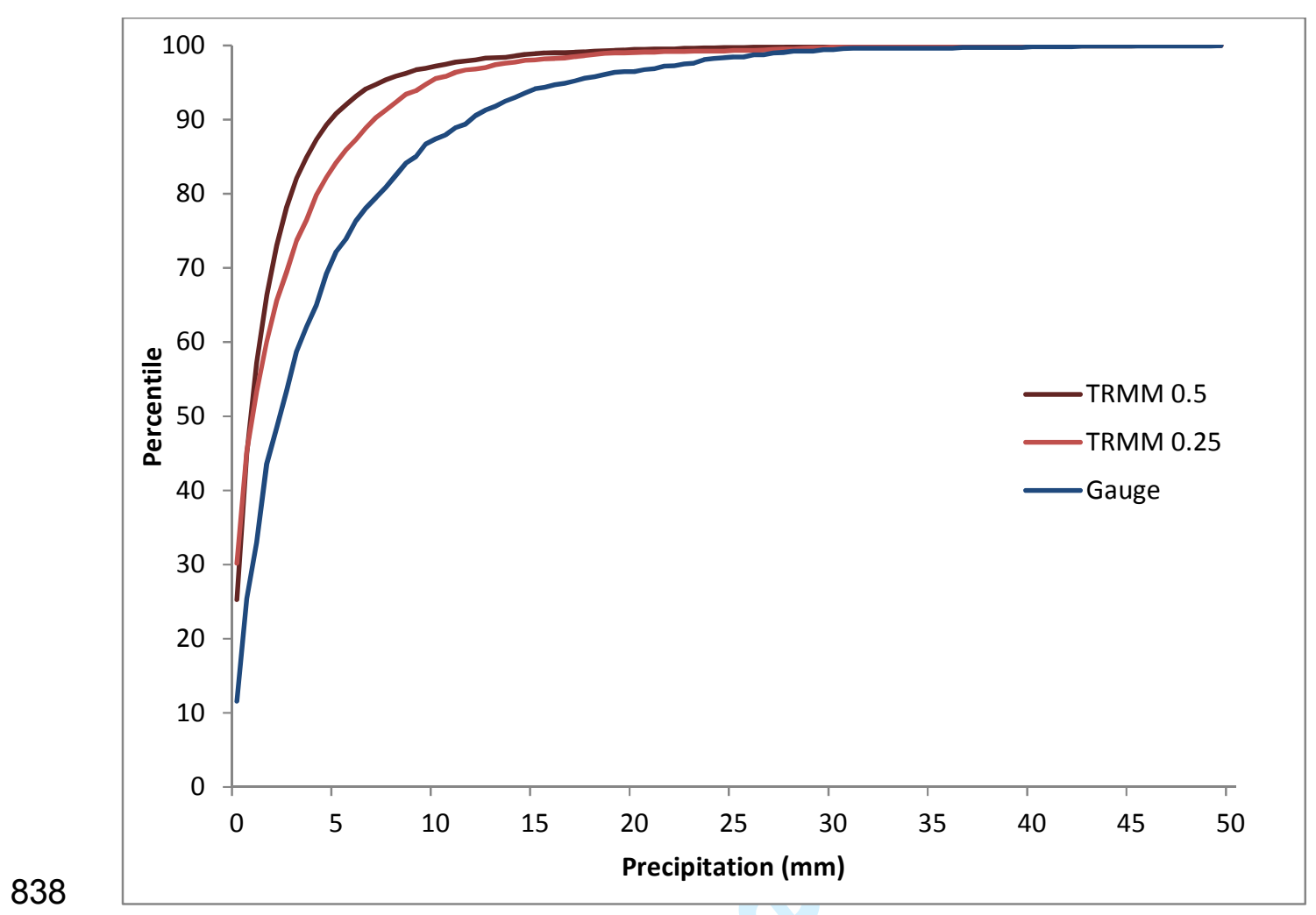

839

840

URL: http://mc.manuscriptcentral.com/hsj 
841 Figure 7 Correlation between nearest $0.5^{\circ}$ TRMM estimates and gauge a) daily and 842 b) monthly precipitation at Naryn 1998-2012

843 a)

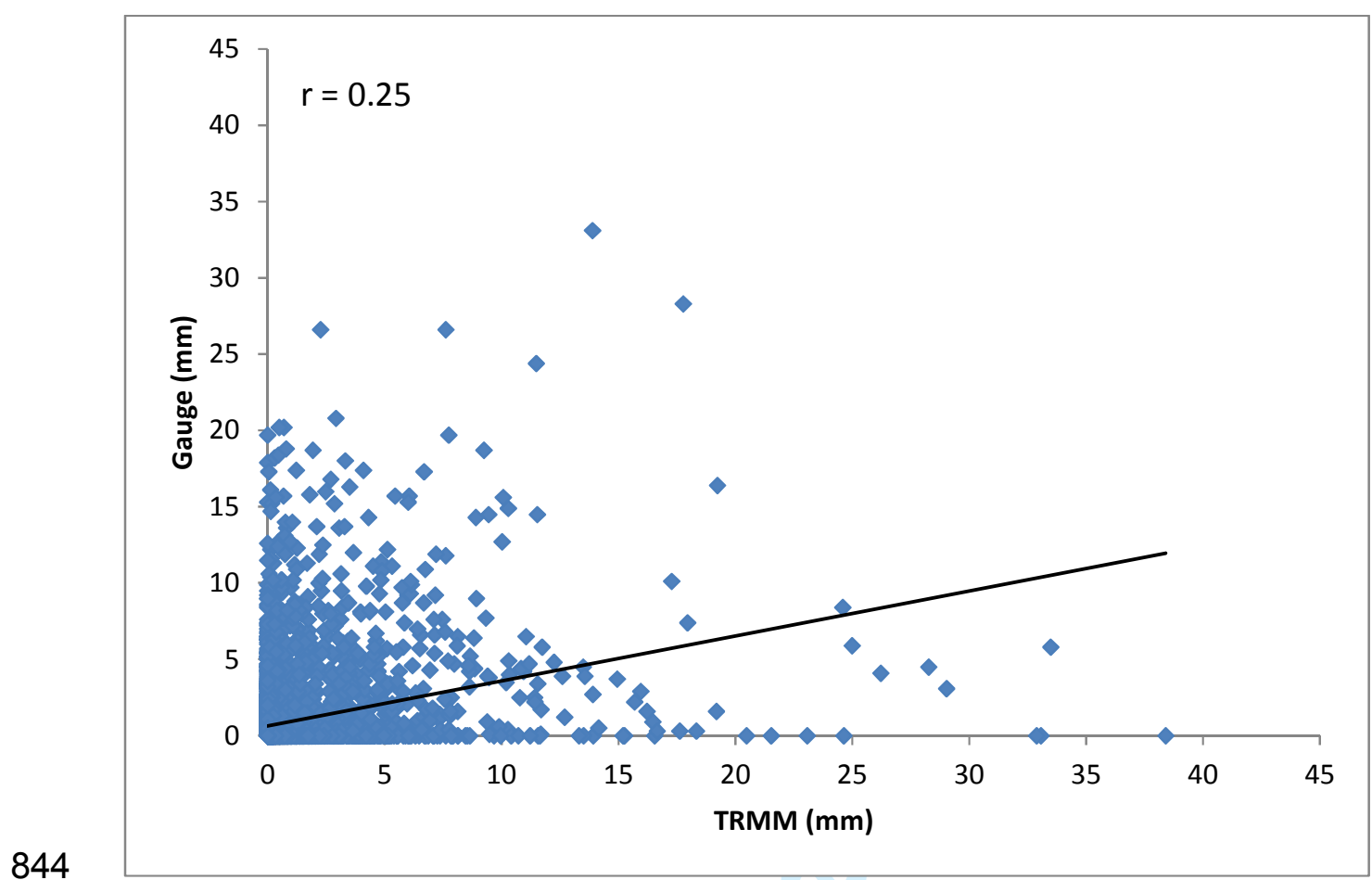

845 b)

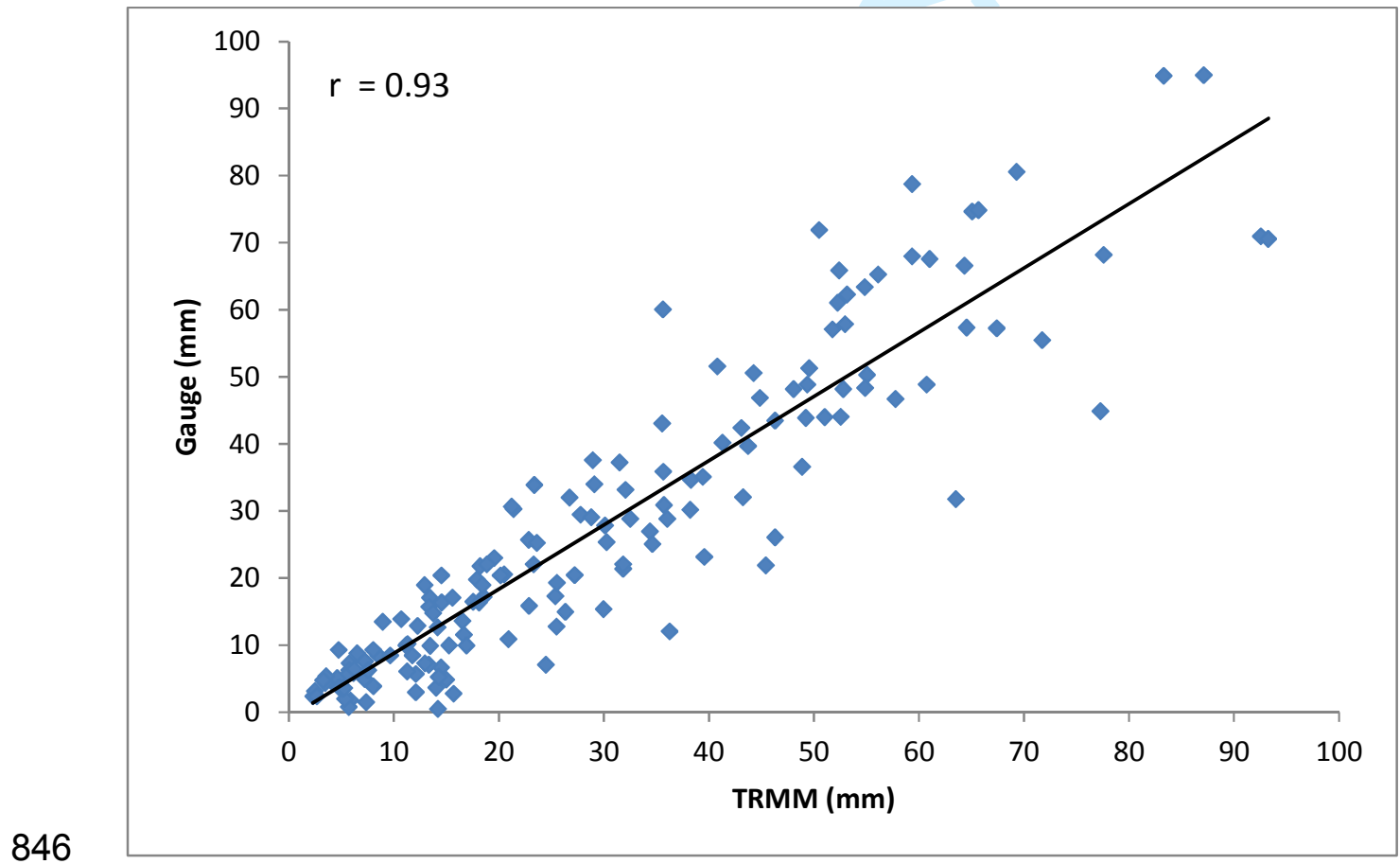

847

URL: http://mc.manuscriptcentral.com/hsj 
848 Figure 8 Correlation between a) daily and b) monthly precipitation gauge at Naryn 849 and concurrent $0.5^{\circ} \mathrm{TRMM}$ estimates 1998-2012.

850 a)

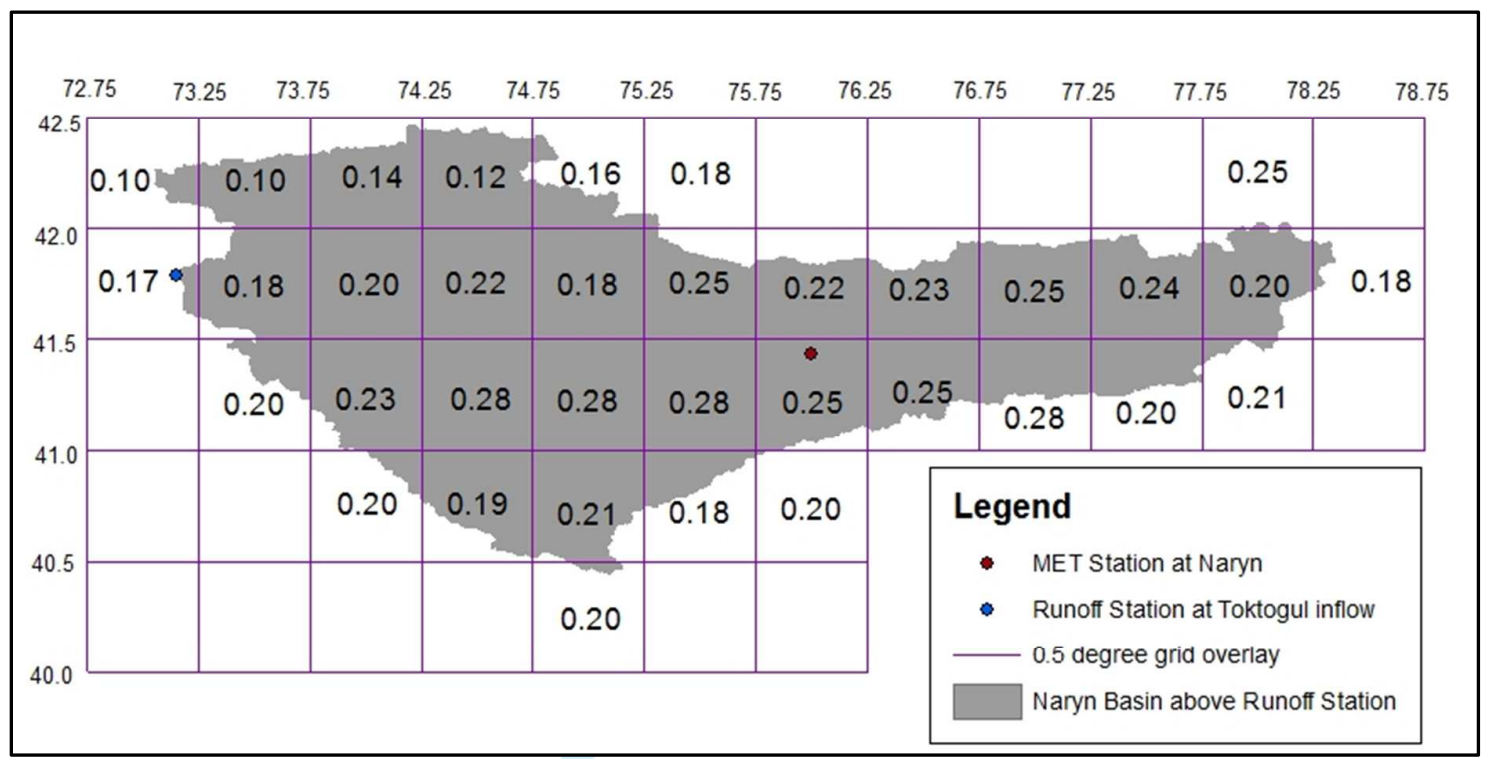

852 b)

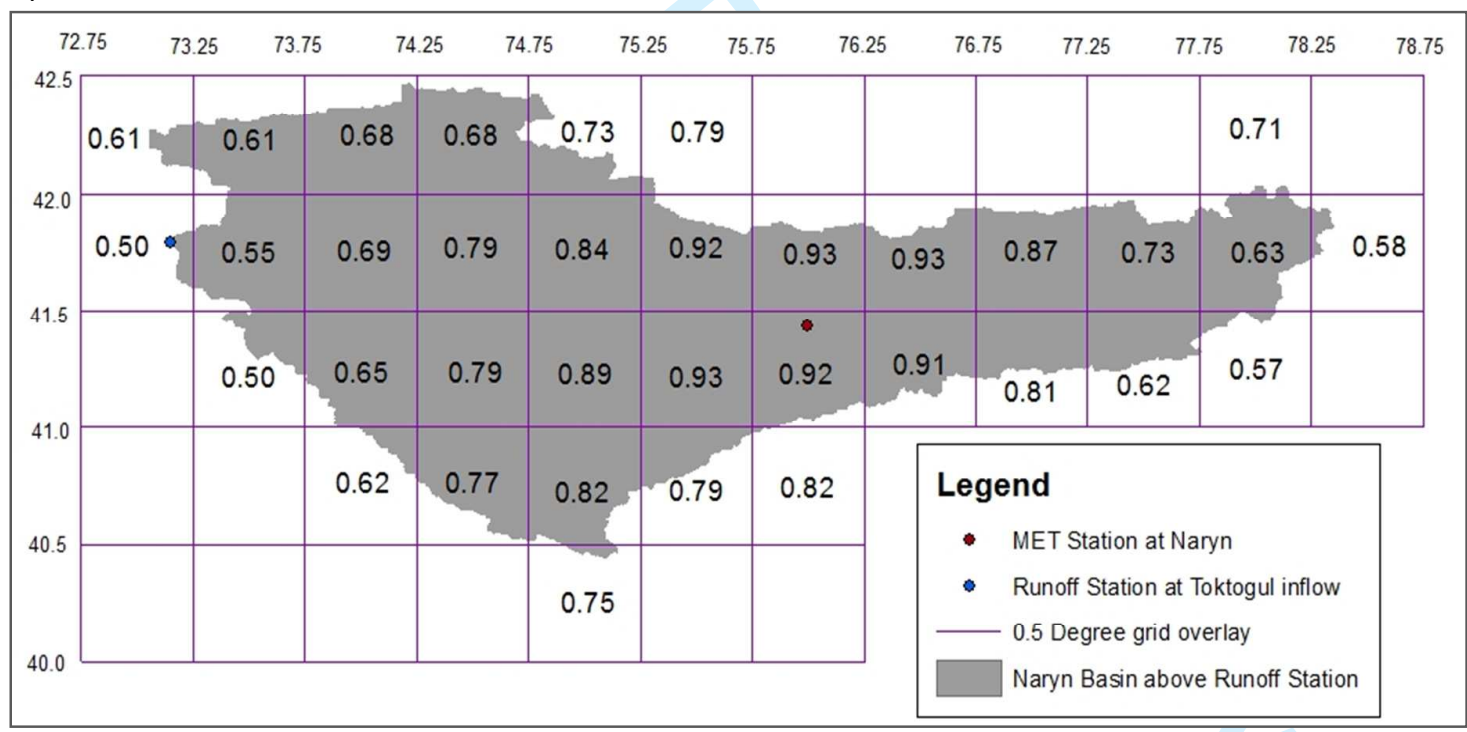

853

854

URL: http://mc.manuscriptcentral.com/hsj 
856 Figure 9 Observed annual (upper panels) and monthly (lower panels) discharge into 857 Toktogul (left) and air temperature at Naryn (right).
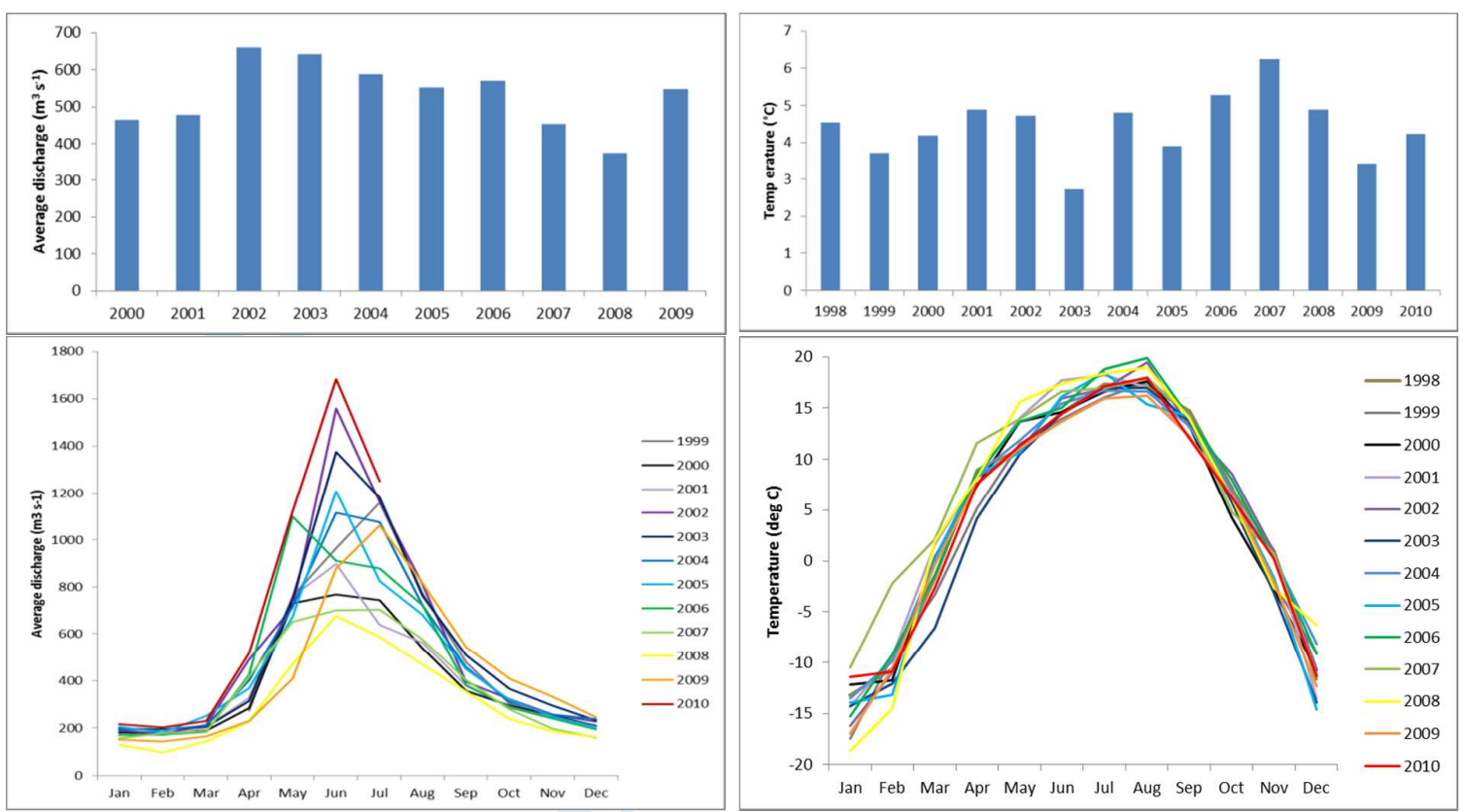

858

859

860

861

34

35

36

37

38

39

40

41

42

43

44

45

46

47

48

49

50

51

52

53

54

55

56

57

58

59

60

URL: http://mc.manuscriptcentral.com/hsj 
Figure 10 Amount of variance in gauged monthly discharge at Toktogul explained by $0.5^{\circ} \mathrm{TRMM}$ with lag=0 (upper left), lag=1 (upper right), lag=2 (lower left) and lag=3 (lower right) months for the period May 1999 to July 2010 inclusive
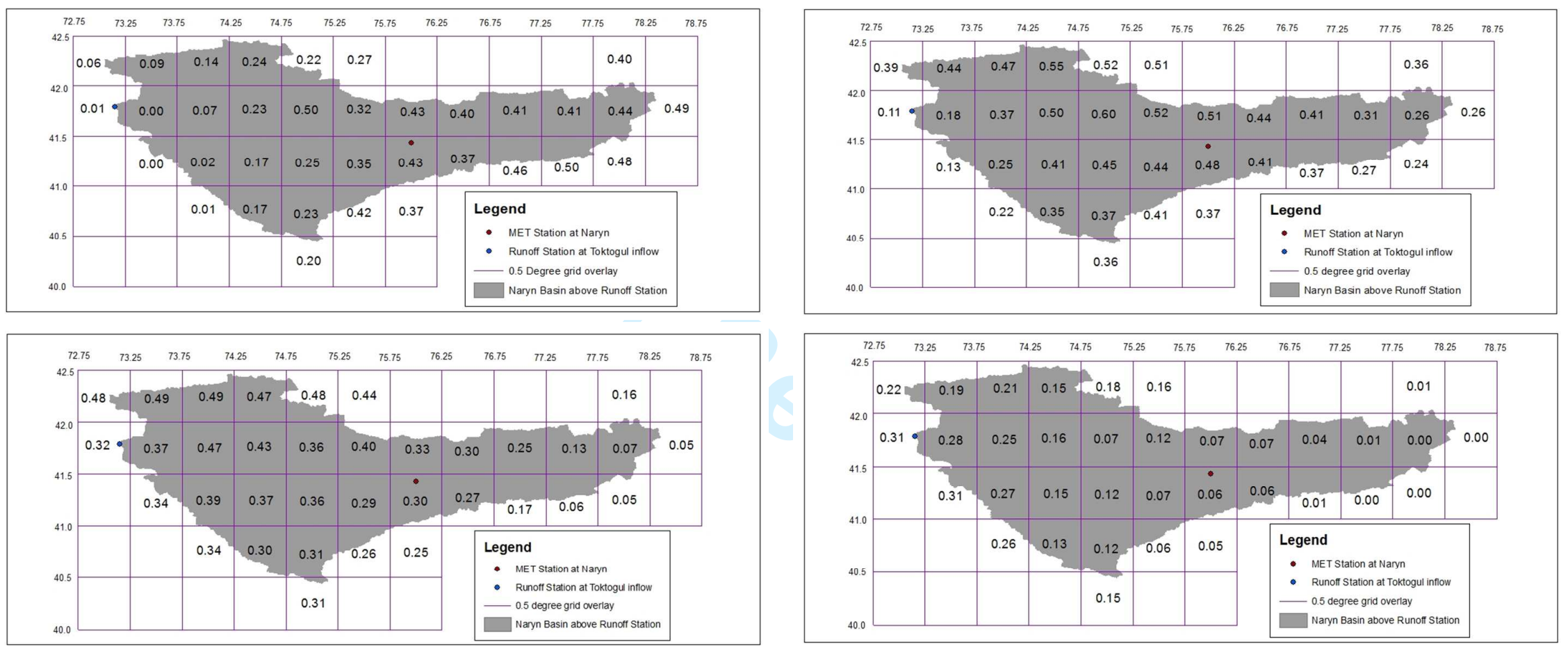
Figure 11 Correlation $(r)$ of gauged flows with lagged predictors averaged over one to six months: temperature (T); precipitation measured at Naryn (PN); precipitation estimates from TRMM for the basin area (PA), and optimum location (PO). For $n=130$ and at $\mathrm{p}=0.05$ significance level, $r_{\text {crit }}=0.17$.
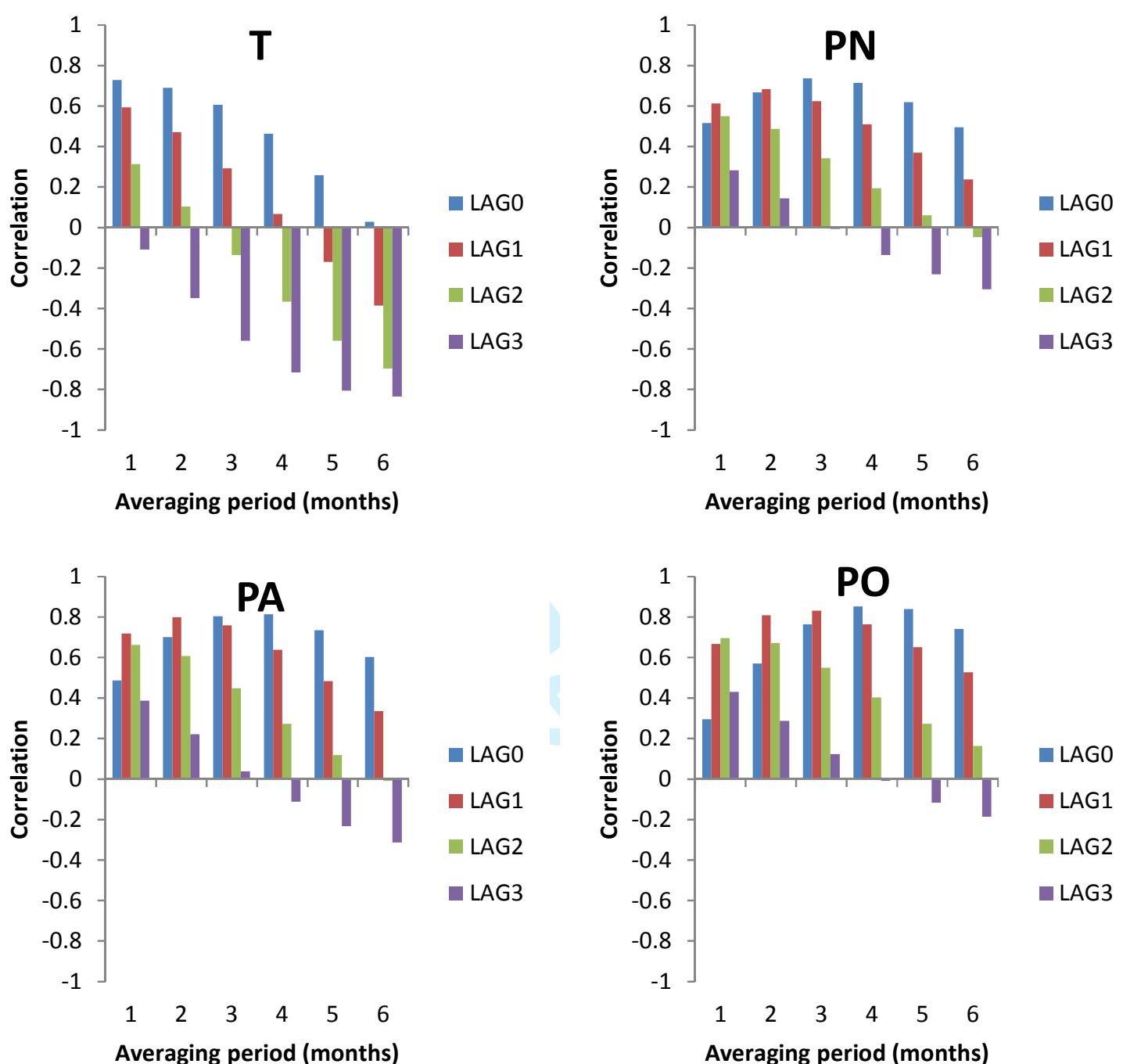
Figure 12 Cross-validated model forecasts with lead-time one (Q1), two (Q2) and three (Q3) months compared with long-term monthly mean discharge (ZOF).
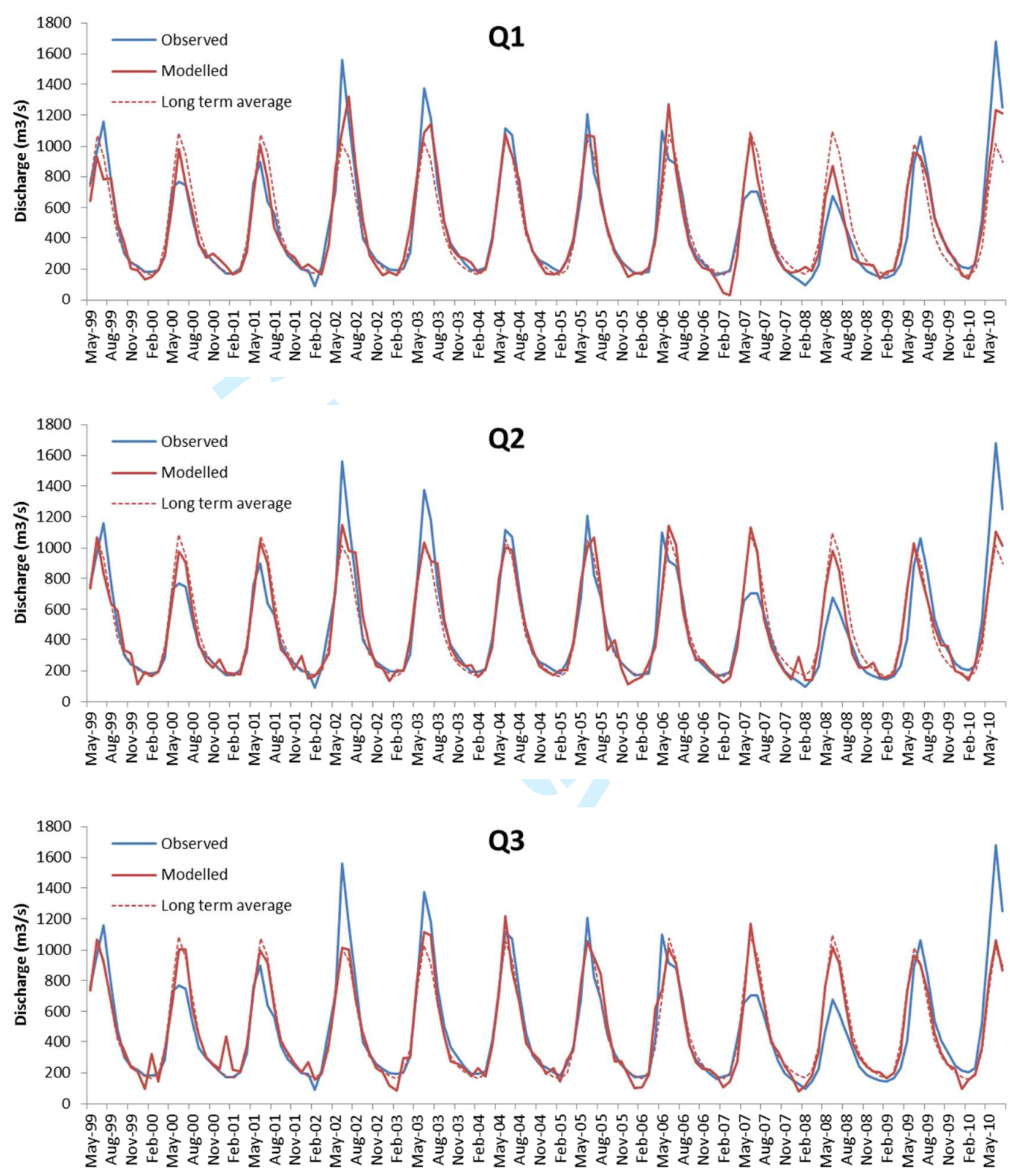

URL: http://mc.manuscriptcentral.com/hsj 
Figure 13 Daily precipitation and discharge series for the River Naryn during melt seasons with large residuals in the $t+1$ forecast (see Q1 in Fig.12).
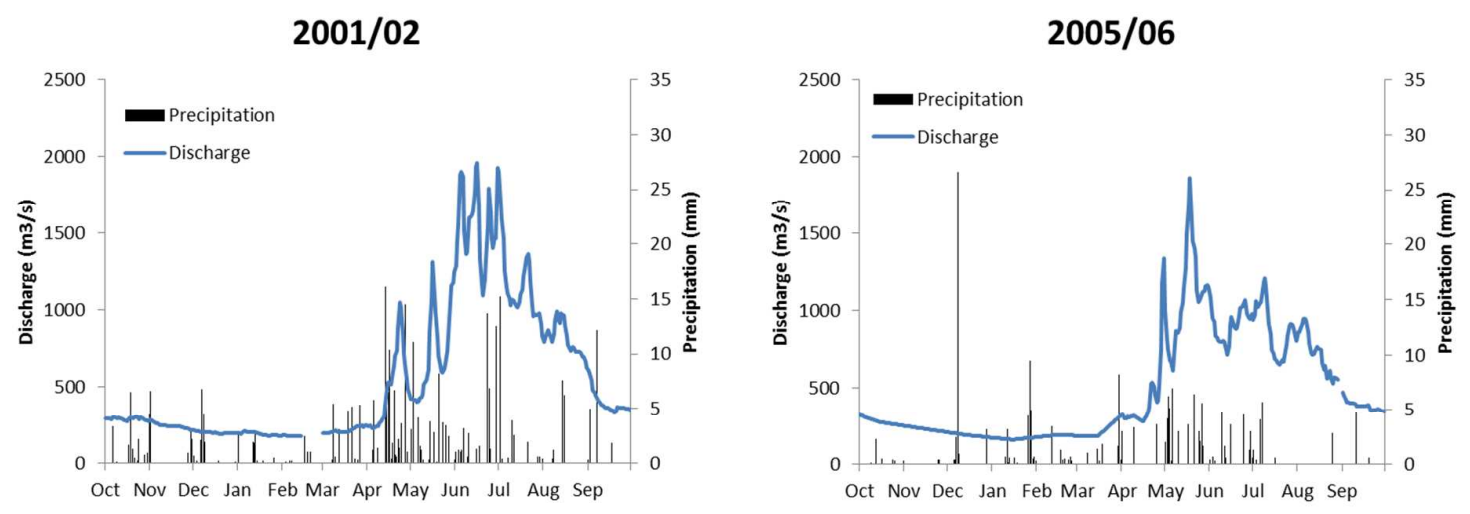

2006/7
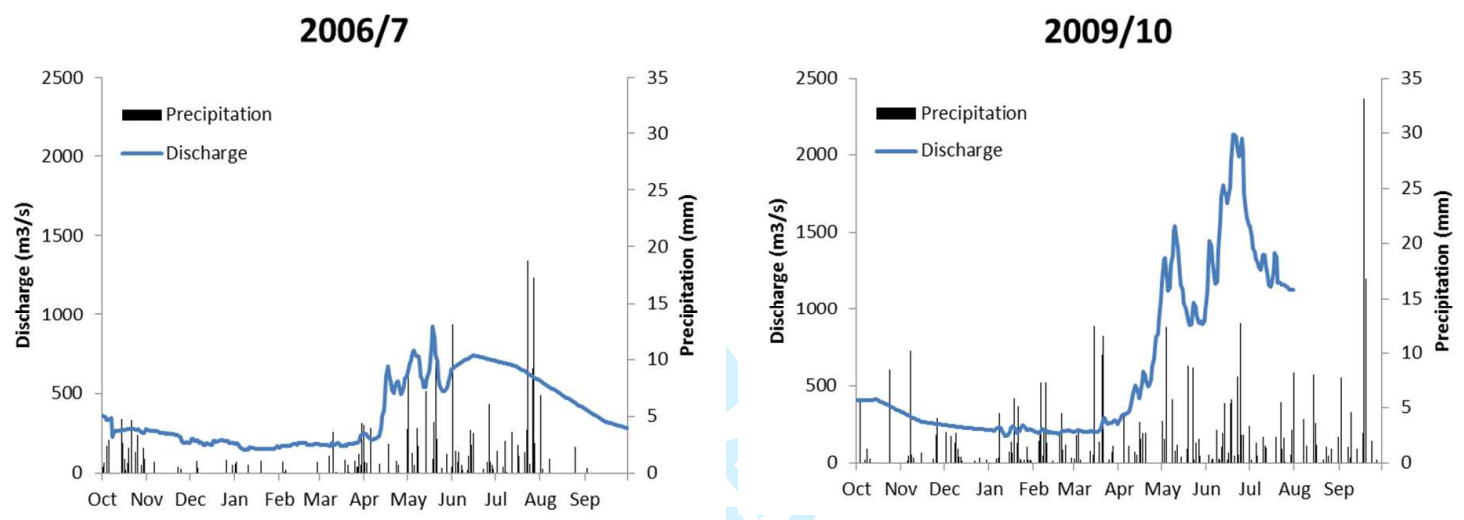

34

35

36

37

38

39

40

41

42

43

44

45

46

47

48

49

50

51

52

53

54

55

56

URL: http://mc.manuscriptcentral.com/hsj 